\title{
Modelling marine emissions and atmospheric distributions of halocarbons and dimethyl sulfide: the influence of prescribed water concentration vs. prescribed emissions
}

\author{
S. T. Lennartz ${ }^{1}$, G. Krysztofiak ${ }^{2, a}$, C. A. Marandino ${ }^{1}$, B.-M. Sinnhuber ${ }^{2}$, S. Tegtmeier ${ }^{1}$, F. Ziska ${ }^{1}$, R. Hossaini ${ }^{3}$, \\ K. Krüger ${ }^{4}$, S. A. Montzka ${ }^{5}$, E. Atlas ${ }^{6}$, D. E. Oram ${ }^{7}$, T. Keber ${ }^{8}$, H. Bönisch ${ }^{8}$, and B. Quack ${ }^{1}$ \\ ${ }^{1}$ GEOMAR Helmholtz-Centre for Ocean Research Kiel, Kiel, Germany \\ ${ }^{2}$ Karlsruhe Institute of Technology, Institute for Meteorology and Climate Research, Karlsruhe, Germany \\ ${ }^{3}$ School of Earth and Environment, University of Leeds, Leeds, UK \\ ${ }^{4}$ University of Oslo, Department of Geosciences, Oslo, Norway \\ ${ }^{5} \mathrm{NOAA} / \mathrm{CMDL}$, Boulder, CO, USA \\ ${ }^{6}$ RSMAS/MAC, University of Miami, Florida, USA \\ ${ }^{7}$ National Centre for Atmospheric Science, Centre for Oceanography and Atmospheric Science, \\ University of East Anglia, Norwich, UK \\ ${ }^{8}$ Goethe University Frankfurt a. M., Institute for Atmospheric and Environmental Sciences, Frankfurt, Germany \\ ${ }^{a}$ now at: LPC2E, UMR 7328, CNRS-Université d'Orléans, 45071 Orléans CEDEX 2, France
}

Correspondence to: S. T. Lennartz (slennartz@geomar.de)

Received: 24 April 2015 - Published in Atmos. Chem. Phys. Discuss.: 30 June 2015

Revised: 23 September 2015 - Accepted: 30 September 2015 - Published: 22 October 2015

\begin{abstract}
Marine-produced short-lived trace gases such as dibromomethane $\left(\mathrm{CH}_{2} \mathrm{Br}_{2}\right)$, bromoform $\left(\mathrm{CHBr}_{3}\right)$, methyliodide $\left(\mathrm{CH}_{3} \mathrm{I}\right)$ and dimethyl sulfide (DMS) significantly impact tropospheric and stratospheric chemistry. Describing their marine emissions in atmospheric chemistry models as accurately as possible is necessary to quantify their impact on ozone depletion and Earth's radiative budget. So far, marine emissions of trace gases have mainly been prescribed from emission climatologies, thus lacking the interaction between the actual state of the atmosphere and the ocean. Here we present simulations with the chemistry climate model EMAC (ECHAM5/MESSy Atmospheric Chemistry) with online calculation of emissions based on surface water concentrations, in contrast to directly prescribed emissions. Considering the actual state of the model atmosphere results in a concentration gradient consistent with model realtime conditions at the ocean surface and in the atmosphere, which determine the direction and magnitude of the computed flux. This method has a number of conceptual and practical benefits, as the modelled emission can respond consistently to changes in sea surface temperature, surface wind
\end{abstract}

speed, sea ice cover and especially atmospheric mixing ratio. This online calculation could enhance, dampen or even invert the fluxes (i.e. deposition instead of emissions) of very short-lived substances (VSLS). We show that differences between prescribing emissions and prescribing concentrations ( $-28 \%$ for $\mathrm{CH}_{2} \mathrm{Br}_{2}$ to $+11 \%$ for $\mathrm{CHBr}_{3}$ ) result mainly from consideration of the actual, time-varying state of the atmosphere. The absolute magnitude of the differences depends mainly on the surface ocean saturation of each particular gas. Comparison to observations from aircraft, ships and ground stations reveals that computing the air-sea flux interactively leads in most of the cases to more accurate atmospheric mixing ratios in the model compared to the computation from prescribed emissions. Calculating emissions online also enables effective testing of different air-sea transfer velocity $(k)$ parameterizations, which was performed here for eight different parameterizations. The testing of these different $k$ values is of special interest for DMS, as recently published parameterizations derived by direct flux measurements using eddy covariance measurements suggest decreasing $k$ values at high wind speeds or a linear relationship with wind speed. 
Implementing these parameterizations reduces discrepancies in modelled DMS atmospheric mixing ratios and observations by a factor of 1.5 compared to parameterizations with a quadratic or cubic relationship to wind speed.

\section{Introduction}

The oceans emit large amounts of halogen- (Penkett et al., 1985; Quack and Wallace, 2003) and sulfur-containing substances (Bates et al., 1992; Watts, 2000) that influence atmospheric chemistry. Organic bromine and iodine in the atmosphere is largely supplied by oceanic emissions of very shortlived substances (VSLS) such as dibromomethane $\left(\mathrm{CH}_{2} \mathrm{Br}_{2}\right)$, bromoform $\left(\mathrm{CHBr}_{3}\right)$ and methyliodide $\left(\mathrm{CH}_{3} \mathrm{I}\right)$ (Lovelock and Maggs, 1973; Hossaini et al., 2013). Also, a large fraction of the atmospheric sulfur loading is due to oceanic emissions of OCS, $\mathrm{CS}_{2}, \mathrm{H}_{2} \mathrm{~S}$ and dimethyl sulfide (DMS; $\mathrm{CH}_{3} \mathrm{SCH}_{3}$ ), the latter being the major compound transporting sulfur from the ocean to the atmosphere (Watts, 2000; Sheng et al., 2015). Thus, we focus on DMS in this study.

Assessing marine emissions of VSLS is crucial, as they significantly influence Earth's atmosphere in both the troposphere and the stratosphere. In the troposphere, brominecontaining VSLS such as $\mathrm{CHBr}_{3}$ and $\mathrm{CH}_{2} \mathrm{Br}_{2}$ contribute to ozone destruction and alter the oxidative capacity (von Glasow et al., 2004; Salawitch, 2006). Oceanic $\mathrm{CH}_{3} \mathrm{I}$ is the main organic iodine compound in the atmosphere (Lovelock and Maggs, 1973) and impacts tropospheric oxidative capacity and ozone destruction (Chameides and Davis, 1980; Saiz-Lopez et al., 2012). Iodine oxides, which can be product gases of $\mathrm{CH}_{3} \mathrm{I}$ are likely to contribute to nucleation and growth of secondary marine aerosol production (O'Dowd and De Leeuw, 2007). DMS emitted to the troposphere is a precursor of secondary organic aerosol and potentially cloud condensation nuclei and thus influences the radiative budget (Charlson et al., 1987). Halogenated VSLS also enhance stratospheric ozone depletion (Sinnhuber and Meul, 2015 ) and thus contribute to the ozone-driven radiative forcing of climate (Hossaini et al., 2015). Despite the short lifetime of $\mathrm{CH}_{3} \mathrm{I}$ (4-7 days) compared to the bromocarbons (6120 days), there is potential for a small fraction of marineproduced $\mathrm{CH}_{3} \mathrm{I}$ to be transported to the stratosphere where it also contributes to ozone depletion (Tegtmeier et al., 2013; Solomon et al., 1994). DMS has a shorter lifetime of $11 \mathrm{~min}-$ 46 h (Barnes et al., 2006; Osthoff et al., 2009) compared to $\mathrm{CH}_{3} \mathrm{I}$. Despite the short lifetime, there is potential even for the very short-lived DMS to be transported to the tropical tropopause layer (TTL) in convective hot spot regions (Marandino et al., 2013a, b).

The impact of marine VSLS emissions on atmospheric chemistry has been studied in chemistry-climate and transport models (e.g. Salawitch et al., 2005; Kerkweg et al., 2006b; Sinnhuber et al., 2009; Liang et al., 2010; Ordóñez et al., 2012). Therein, marine emissions of the VSLS have mainly been based on prescribed boundary layer mixing ratios (Aschmann et al., 2009) or emission scenarios (Warwick et al., 2006; Liang et al., 2010; Ordóñez et al., 2012; Hossaini et al., 2013). However, prescribing emissions in atmospheric models lacks the impact of the atmospheric boundary layer mixing ratio on the concentration gradient. This concentration gradient at the interface between ocean and atmosphere directly influences the emissions, as it determines the direction and magnitude of the flux. The lack of potential feedbacks can result in a modelled atmospheric surface concentration inconsistent with the oceanic surface concentration.

Here, we evaluate a conceptually different way of considering marine emissions in chemical climate models that is based on a consistent concentration gradient between ocean and atmosphere. In contrast to previous approaches of either specifying atmospheric surface mixing ratios or specifying sea-to-air fluxes, water concentrations are prescribed and emissions are calculated online. Thus, the concentration gradient at the interface and the emissions are consistent with the atmospheric boundary layer and the ocean surface, and the emissions can respond to the actual state of the atmosphere. The approach is applied to established concentration climatologies of short-lived halocarbons $\left(\mathrm{CH}_{2} \mathrm{Br}_{2}\right.$, $\mathrm{CHBr}_{3}, \mathrm{CH}_{3} \mathrm{I}$ ) and sulfur compounds (DMS) that share common characteristics such as supersaturation in the surface ocean and marine production. For the halocarbons, this setup is applied for the first time and uses surface ocean concentration climatologies derived from observations by Ziska et al. (2013). Oceanic DMS emissions have been evaluated in coupled ocean-atmosphere models (Kloster et al., 2006; Cameron-Smith et al., 2011) or modelled online during a test for the implementation of different submodels (Kerkweg et al., 2006b). In our study, the focus lies on how to consider oceanic emissions in a stand-alone atmospheric model, and uses the most updated DMS concentrations available (Lana et al., 2011). Additionally, we compare the output of the two methods with observations from aircraft and ship campaigns.

Prescribing water concentrations and calculating emissions online enables convenient testing of different air-sea gas exchange parameterizations. Air-sea gas exchange is calculated as the product of the concentration gradient between air and water at the surface and the transfer velocity. The latter needs to be parameterized, and many different parameterizations have been published (see e.g. Wanninkhof et al., 2009 for a summary). Most parameterizations relate the transfer velocity to wind speed (e.g. Liss and Merlivat, 1986; Wanninkhof and McGillis, 1999; Nightingale et al., 2000; Ho et al., 2006), but others take the effect of bubble-mediated transfer (Asher and Wanninkhof, 1998) or enhancement by rain (Ho et al., 1997, 2004) into account. Testing a variety of different parameterizations on prescribed water concentrations to calculate atmospheric abundances provides information on the uncertainties of global emission estimates.

The experimental set-up consists of two steps. First, we prescribed surface water concentrations in the chemistry cli- 
mate model EMAC (ECHAM5/MESSy Atmospheric Chemistry) (Jöckel et al., 2006, 2010) and air-sea exchange of VSLS was then calculated online by the submodel AIRSEA (Pozzer et al., 2006). The model results are then evaluated and compared to a simulation where the difference results from prescribed VSLS emissions (PE). To compare the simulation set-up with prescribed emissions to the set-up with prescribed water concentrations, we used the same concentration climatologies that were used to create the emission climatologies. In our study, these concentration and corresponding emission climatologies were published by Ziska et al. (2013) for the halocarbons and Lana et al. (2011) for DMS. The modelled atmospheric mixing ratios of the gases are compared to measurements from time series of groundbased stations, ship and aircraft campaigns in order to identify whether the online calculation is simulating the atmospheric mixing ratios more accurately. In a second step, we use the coupled module to test the sensitivity of the global emissions to eight different, frequently used or recently published, transfer velocity parameterizations.

\section{Model set-up and data description}

\subsection{The atmosphere-chemistry model EMAC}

The EMAC model is a global atmospheric chemistry climate model described in Jöckel et al. (2006, 2010). ECHAM5/MESSy includes submodels describing processes of the troposphere and middle atmosphere as well as interaction with land and human influences. Air-sea gas exchange is calculated in EMAC with the submodule AIRSEA, as described by Pozzer et al. (2006).

The numerical simulations were nudged towards the European Centre for Medium-Range Weather Forecasts (ECMWF) ERA-Interim reanalysis (Dee et al., 2011) every $6 \mathrm{~h}$ (temperature, divergence, vorticity, surface pressure). The resolution of the EMAC atmosphere was $\sim 2.8^{\circ} \times 2.8^{\circ}(\mathrm{T} 42)$ and 39 vertical hybrid pressure levels up to $0.01 \mathrm{hPa}$ (L39). The effect of resolution on the results tested with a finer resolution (T106) was only minor (see Table S2 in the Supplement). The atmospheric model as well as the submodel AIRSEA uses a time step of $600 \mathrm{~s}$. The convective transport follows the scheme of Tiedtke (1989) and the tracer advection is described in Lin and Rood (1996). An overview of these nudged simulation set-ups can be found in Sect. 2.3.

The simulations include the four very short-lived species, $\mathrm{CH}_{2} \mathrm{Br}_{2}, \mathrm{CHBr}_{3}, \mathrm{CH}_{3} \mathrm{I}$ and DMS, and simplified atmospheric loss reactions for them. The loss reactions include

- oxidation with $\mathrm{OH}, \mathrm{O}\left({ }^{1} \mathrm{D}\right), \mathrm{Cl}$ and photolysis for $\mathrm{CHBr}_{3}$ and $\mathrm{CH}_{2} \mathrm{Br}_{2}$ following the reactions rates by Sander et al. (2011);

- oxidation with $\mathrm{OH}, \mathrm{Cl}$ and photolysis for $\mathrm{CH}_{3} \mathrm{I}$ (Sander et al., 2011);
- and oxidation with $\mathrm{OH}$ and $\mathrm{O}\left({ }^{3} \mathrm{P}\right)$ for DMS (Sander et al., 2011).

EMAC uses monthly mean concentrations of $\mathrm{OH}$, developed and evaluated for the TransCom-CH4 model intercomparison project, and discussed in detail by Patra et al. (2014). Monthly mean photolysis rates for VSLS were calculated by the TOMCAT CTM (chemical transport model) which has been used extensively to examine the tropospheric chemistry of VSLS (e.g. Hossaini et al., 2013). These fields were provided at a horizontal resolution of $2.8^{\circ} \times 2.8^{\circ}$ (longitude $\times$ latitude) and on 60 vertical levels (surface to $\sim 60 \mathrm{~km}$ ). TOMCAT calculates photolysis rates online using the code of Hough (1988) which considers both direct and scattered radiation. Within TOMCAT, this scheme is supplied with surface albedo, monthly mean climatological cloud fields and ozone and temperature profiles. The photolysis rates have recently been used and evaluated as part of the ongoing TransCom-VSLS model intercomparison project (http://www.transcom-vsls.com).

The simulated atmospheric lifetimes in our set-up generally agree well with published estimates for these gases, indicating that the basic assumption of the simplified chemistry applied here is valid. The local mean tropical $\left(20^{\circ} \mathrm{N}-20^{\circ} \mathrm{S}\right)$ lifetime of $\mathrm{CH}_{2} \mathrm{Br}_{2}$ in the troposphere in our model study is 143 days and thus lies below 167 days, which was found in Hossaini et al. (2010). The mean tropospheric tropical lifetime of $\mathrm{CHBr}_{3}$ is 20 days in our study, which is consistent within $10 \%$ with a recent reevaluation of $\mathrm{CHBr}_{3}$ lifetime by Papanastasiou et al. (2014), together with a recent reevaluation of the reaction of $\mathrm{OH}$ with $\mathrm{CHBr}_{3}$ by Orkin et al. (2013). The local lifetime of $\mathrm{CH}_{3} \mathrm{I}$ in our study is 3 days, which is in accordance with the study of Tegtmeier et al. (2013). The tropical lifetime of DMS in our study ranges between less than 1 day and up to 3 days and is thus within but at the higher end of the range of $11 \mathrm{~min}-46 \mathrm{~h}$ (Barnes et al., 2006; Osthoff et al., 2009).

\subsection{Parameterizations of air-sea gas exchange}

In this study, the AIRSEA submodel (Pozzer et al., 2006) and its approach for air-sea gas exchange was adopted, using the two-layer model (Liss and Slater, 1974). Marine emissions $(F)$ of gases are calculated as the product of the concentration gradient between air and water concentration of the gas $(\Delta c)$ and the transfer velocity $(k ;$ Eq. 1$)$, which needs to be parameterized.

$F=k \cdot \Delta c=k \cdot\left(c_{\mathrm{W}}-H \cdot c_{\mathrm{air}}\right)$

with $c_{\mathrm{w}}$ being the water concentration, $H$ the Henry constant (dimensionless, water over air) and $c_{\text {air }}$ the concentration of the gas in air which was taken from the modelled atmosphere in the respective time step. Henry constants and their temperature dependencies are taken from Moore et al. (1995) for the halocarbons and De Bruyn et al. (1995) for DMS. 
The transfer velocity $k$ comprises air- $\left(k_{\text {air }}\right)$ and water-side $\left(k_{\mathrm{w}}\right)$ transfer velocities (Eq. 2) in all parameterizations with the Henry constant $(H)$, air temperature $\left(T_{\text {air }}\right)$ and the ideal gas constant $(R)$ :

$k=\left(\frac{1}{k_{\mathrm{w}}}+\frac{R \cdot H \cdot T_{\mathrm{air}}}{k_{\mathrm{air}}}\right)^{-1}$.

The water-side transfer velocity $k_{\mathrm{w}}$ is often parameterized in relation to wind speed with linear (e.g. Liss and Merlivat, 1986), quadratic (e.g. Ho et al., 2006) or cubic (e.g. Wanninkhof and McGillis, 1999) dependencies. Differences between these parameterizations arise from different techniques to determine $k_{\mathrm{w}}$. The $k_{\mathrm{W}}$ parameterizations tested in our study result from tracer release experiments in wind tanks (Liss and Merlivat, 1986), from deliberate tracer techniques in the open ocean (Nightingale et al., 2001; Ho et al., 2006) or from direct flux measurements using eddy covariance (Wanninkhof et al., 1999; Marandino et al., 2009; Bell et al., 2013). Additional drivers of gas exchange, e.g. bubblemediated transfer (e.g. Asher and Wanninkhof, 1998) and enhancement in the presence of rain (e.g. Ho et al., 2004) are discussed. Bubble-mediated transfer has been suggested to be influential for gases with low solubilities since they more quickly escape from the liquid phase into the bubbles. Asher and Wanninkhof (1998) reanalysed data from a dual tracer experiment and found a better fit when bubble-mediated gas transfer was considered in the flux calculations. Bubbles are more easily transported to the surface and released to the atmosphere, thereby adding to the total flux. Rain is believed to increase the flux under calm wind conditions due to an alteration of the sea surface, which was tested in a dual tracer experiment in the laboratory (Ho et al., 2004). Other factors are known to influence air-sea gas exchange such as the presence of surfactants, but parameterizations including that effect are only marginally explored (Tsai and Liu, 2003) and require global distributions of surfactants that are currently not available. First steps of including surfactants in global models are currently discussed (Elliott et al., 2014; Burrows et al., 2014).

For sparingly soluble gases, $k_{\mathrm{w}}$ dominates the transfer velocity, and $k_{\text {air }}$ is often neglected as a simplification. For more soluble gases, McGillis et al. (2000) found that considering $k_{\text {air }}$ alters the flux to the atmosphere significantly when low temperatures or moderate wind speeds prevail. The parameterizations of $k_{\text {air }}$ according to Kerkweg et al. (2006a, Eqs. 3 and 4 therein) assumes a dependency on the friction velocity and surface wind speed, which is considered in the AIRSEA submodel.

The transfer velocity needs to be adapted to each gas by scaling it with the dimensionless Schmidt number in water for $k_{\mathrm{w}}$ and the Schmidt number in air for $k_{\text {air }}$ divided by the Schmidt number that the specific parameterization was normalized to, which is in most cases either 600 or 660 . The Schmidt number is the ratio of the diffusion coefficient of the compound to the kinematic viscosity of the surrounding medium. Following the approach of the AIRSEA submodel, the Schmidt number in water is estimated by scaling the $\mathrm{CO}_{2}$ Schmidt number in water (Wannikof, 1992; Wilke and Chang, 1955), while the Schmidt number in air is calculated from air viscosity and diffusivity of the gas in air (Lymann et al., 1990).

\subsection{Experimental set-up}

\subsubsection{Prescribed concentrations and prescribed emissions}

The experimental set-up consists of two steps. First, we compare emissions and atmospheric mixing ratios from prescribed water concentrations (PWC) with those derived from prescribed emissions (PE) (Fig. 1). For the PWC and PE setup, two different submodels are used to calculate the emissions in EMAC: in the PE approach, emission climatologies are prescribed offline using the submodel OFFLEM (Kerkweg et al., 2006b). For the PWC set-up, emissions (or depositions) are calculated online using the submodel AIRSEA (Pozzer et al., 2006). Details of the simulation set-ups for simulations 1 (PWC) and 2 (PE) can be found in Table 1. Both simulations cover a period of 24 years (1990-2013) to average out interannual variabilities in emissions and to ensure that the model output can be subsampled specifically at the times of atmospheric observations specified in Sect. 2.4.

In simulation 1 , we prescribe water concentration climatologies for the halocarbons from Ziska et al. (2013, Z13) and for DMS from Lana et al. (2011, L11). The assumption of constant water concentrations despite loss by emissions is justified by the relatively small emissions compared to the absolute amount of gas in the oceanic mixed layer and the fast production of the compounds in water (e.g. Hopkins and Archer, 2014; Hepach et al., 2015). The modelled emissions from the PWC set-up are compared to the original Z13 and L11 emission climatologies. In the same manner, resulting atmospheric mixing ratios in the PWC simulation are compared to atmospheric concentrations from the PE setup with prescribed emissions from Z13 and L11. The emission climatology from Z13 is based on constant water and atmospheric concentrations extrapolated from $\sim 5000$ measurements, using 6-hourly ERA-Interim wind fields and the Nightingale et al. (2000) parameterization for water-side transfer velocity. The L11 concentration climatology is based on $\sim 40000$ measurements and surface wind data for the emission climatologies from the NCEP/NCAR reanalysis project with a water-side transfer velocity parameterized according to Nightingale et al. (2000, N00) and an air-side transfer velocity according to Kondo (1975). The climatologies, prescribing emissions and concentrations of the gases of interest $\left(\mathrm{CH}_{2} \mathrm{Br}_{2}, \mathrm{CHBr}_{3}, \mathrm{CH}_{3} \mathrm{I}\right.$ and DMS $)$ were regridded to the T42 grid of EMAC with ncregrid (Jöckel, 2006), which is in all four cases coarser than the original grid de- 

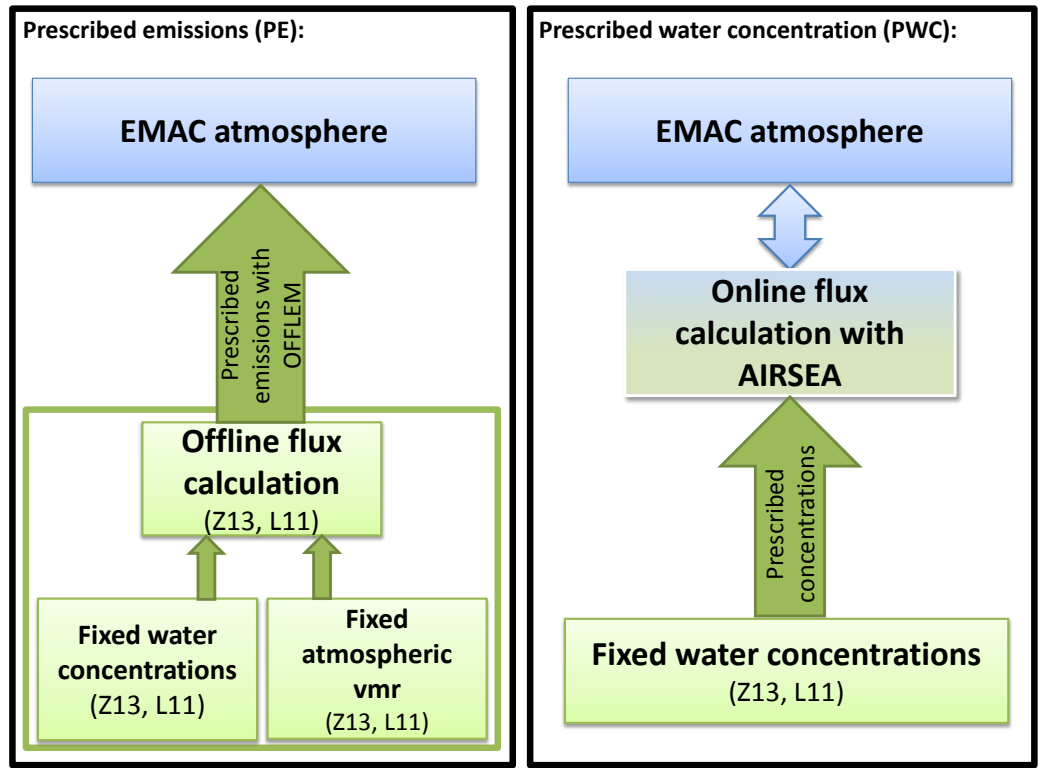

Figure 1. Schematic overview of the set-up of prescribed emissions (PE, left panel) and online-calculated fluxes based on prescribed water concentrations (PWC, right panel) implemented in EMAC. Climatologies of fixed water and atmospheric concentrations in Ziska et al. (2013; Z13) and Lana et al. (2011; L11) were used to compute a global emission estimate, and the resulting interannual mean emission climatology is prescribed in EMAC using the submodule OFFLEM (PE, left panel). Calculating emissions online based on prescribed concentration (Z13, L11) considers the current state of the atmosphere during the calculation of emissions in the submodule AIRSEA (PWC, right panel).

Table 1. Set-up of model simulations evaluated in this study. PWC: prescribed water concentration, PE: prescribed emissions, AIRSEA: submodel for online calculation of emissions, OFFLEM: submodel for prescribing emissions.

\begin{tabular}{|c|c|c|c|c|c|c|}
\hline & Abbreviation & $\begin{array}{l}k_{\mathrm{W}^{-}} \\
\text {parameterization }\end{array}$ & $\begin{array}{l}\text { Emission calculation, } \\
\text { submodule }\end{array}$ & $\begin{array}{l}\text { Rain } \\
\text { effect }\end{array}$ & $\begin{array}{l}\text { White cap } \\
\text { coverage effect }\end{array}$ & Period \\
\hline 1 & PWC & Nightingale et al. (2000) & PWC, AIRSEA & No & No & 1990-2013 \\
\hline 2 & $\mathrm{PE}$ & $\begin{array}{l}\text { Prescribed emissions, no online } \\
\text { calculation, } k_{\mathrm{W}} \text { in original pub- } \\
\text { lications N00 }\end{array}$ & PE, OFFLEM & No & No & $1990-2013$ \\
\hline 3 & LM86 & Liss and Merlivat (1986) & PWC, AIRSEA & No & No & 2010-2011 \\
\hline 4 & W99 & Wanninkhof et al. (1999) & PWC, AIRSEA & No & No & 2010-2011 \\
\hline 5 & N00 & Nightingale et al. (2000) & PWC, AIRSEA & No & No & 2010-2011 \\
\hline 6 & H06 & Ho et al. (2006) & PWC, AIRSEA & No & No & 2010-2011 \\
\hline 7 & $\mathrm{H} 06 \mathrm{r}$ & Ho et al. (2006) & PWC, AIRSEA & Yes & No & 2010-2011 \\
\hline 8 & A98 & Asher and Wanninkhof (1998) & PWC, AIRSEA & No & Yes & 2010-2011 \\
\hline 9 & B13m & $\begin{array}{l}\text { Bell et al. (2013) modified, only } \\
\text { DMS }\end{array}$ & PWC, AIRSEA & No & No & 2004-2013 \\
\hline 10 & M09 & Marandino et al. (2009) & PWC, AIRSEA & No & No & 2004-2013 \\
\hline
\end{tabular}

scribed in Z13 and L11 ( $1^{\circ} \times 1^{\circ}$ in both). It has to be noted that this leads to a smoothing of small, local hotspots, but we assume this to be negligible since we compare emissions on a global scale.

Besides the concentrations taken from the climatologies Z13/L11, the air-sea calculation requires information on sea surface temperature, salinity and wind. The mean sea surface temperature in the model for simulation 1 (1990-2013) was $15.95^{\circ} \mathrm{C}, 15.82^{\circ} \mathrm{C}$ in $\mathrm{Z} 13$ and $16.22^{\circ} \mathrm{C}$ in $\mathrm{L} 11$. The mean wind speed in the EMAC simulations (PWC, PE) was
$7.51 \mathrm{~m} \mathrm{~s}^{-1}$, which is slightly larger than the wind speed used to calculate the emission climatologies in Z13 (EMAC is $4.7 \%$ larger) and L11 (EMAC is $2.7 \%$ larger). Sea surface salinity is prescribed with a constant value of $0.4 \mathrm{~mol} \mathrm{~L}^{-1}$ in our model simulations as opposed to spatially varying salinity in Z13 and L11. A 2-year simulation comparing the effects of a constant salinity versus the Z13 climatology revealed a low effect on global emissions $(<3 \%)$, which is in accordance with findings of Ziska et al. (2013). Compared to the calculation of the Schmidt number in the publications by 
Z13 and L11, the submodel AIRSEA uses a different empirical, temperature-dependent equation to calculate the Schmidt number. In AIRSEA, the Schmidt number of $\mathrm{CO}_{2}$ at the respective temperature is calculated and then adapted with the molar volume to the Schmidt number of the gas of interest (Wilke and Chang, 1955; Hayduk and Laudie, 1974). In Z13, the Schmidt number is calculated by averaging the diffusion coefficient according to Hayduk and Laudie (1974) and Wilke and Chang (1955) and then dividing by the dynamic viscosity of seawater at varying temperatures and a constant salinity of 35. In L11, the Schmidt number is calculated according to Saltzman et al. (1993). The resulting differences are negligible at sea surface temperatures higher than $10^{\circ} \mathrm{C}$ and grow largest at $0{ }^{\circ} \mathrm{C}$, where they are still less than $15 \%$. Since the Schmidt number is then normalized to the Schmidt number of $\mathrm{CO}_{2}$, the resulting difference becomes small and does not lead to significant differences in the global emission estimates of all four compounds. Differences in other influential input parameters for emission calculation between our PWC set-up and Z13 and L11 are thus small, ensuring that differences in emissions between PWC and Z13 and L11 can be attributed to the consideration of the actual state of the atmosphere in the PWC set-up.

\subsubsection{Transfer velocity parameterizations}

In the second part of the study, we test the sensitivity of the global emissions towards eight different transfer velocity parameterizations. These tests cover a 2-year time span (20102011) with 1 year (2009) as spin-up. The simulations 3-6 (Table 1) test the impact of different water-side transfer velocity parameterizations related to wind speed. The parameterizations tested in this study are illustrated in Fig. 2. With increasing wind speed, the differences between the transfer velocity parameterizations grow larger; hence, testing these parameterizations yields a range of global emission estimates that reflects this uncertainty. Parameterizations and the general description of air-sea gas exchange calculation are described in Sect. 2.2.

Table 1 provides an overview of all performed simulations. Simulation 3 uses the 3-step linear parameterization of Liss and Merlivat (1986, LM86), simulation 4 the cubic relationship by Wanninkhof and McGillis (1999, W99), simulation 5 the quadratic parameterization by Nightingale et al. (2000, N00), and simulation 6 the quadratic transfer velocity parameterization by Ho et al. (2006, H06). The effect of rain (simulation 7 in Table 1) was tested adding the Ho et al. (1997) rain effect parameterization to the H06 transfer velocity parameterization (see Pozzer et al., 2006, Eqs. 10 and 11). White cap coverage according to Asher and Wanninkhof (1998, A98) considers bubble-mediated gas exchange and is used in simulation 8. The different parameterizations (LM86, W99, N00, H06) were available from the AIRSEA version of Pozzer et al. (2006). The N00 parameterization was normalized to

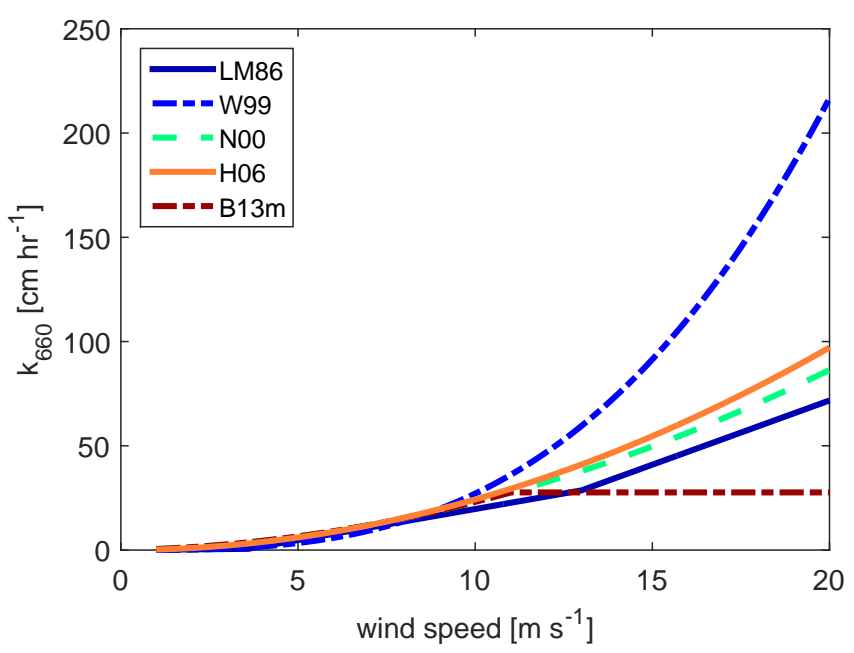

Figure 2. Parameterizations for water-side transfer velocity of airsea gas exchange $k_{\mathrm{W}}$ for a Schmidt number of 660 that are tested in this study: the linear parameterization LM96 (Liss and Merlivat, 1986), the cubic parameterization W99 (Wanninkhof and McGillis, 1999), the quadratic parameterization N00 (Nightingale et al., 2000) and H06 (Ho et al., 2006), the parameterization modified according to Bell et al. (2013, B13m) with a levelling off at wind speeds higher than $11 \mathrm{~m} \mathrm{~s}^{-1}$, and the linear parameterization M09 (Marandino et al., 2009).

the Schmidt number of 600 as in the original publication by Nightingale et al. (2000), while 660 was used in Z13.

Two additional simulations including only DMS were performed to test the effect of two recently published parameterizations of $k_{\mathrm{w}}$. These two parameterizations have been derived from in situ DMS eddy covariance measurements and deviate from previously published parameterizations. Bell et al. (2003) observed that the transfer velocity does not increase at wind speeds higher than $11 \mathrm{~m} \mathrm{~s}^{-1}$. Marandino et al. (2009) found a linear dependency between wind speed and the transfer velocity $k_{\mathrm{w}}$ for DMS. Both simulations cover the period of 2004-2013, since observations from this period were available for comparison. These two parameterizations for $k_{\mathrm{w}}$ were added to the submodule code of AIRSEA (for equations see Table 4). The modification of the code included a parameterization based on results of the study from Bell et al. (2013, B13m) with a conservative approach, in which the N00 parameterization was used at wind speeds below $11 \mathrm{~m} \mathrm{~s}^{-1}$ and kept constant at higher wind speeds to account for the missing increase of $k_{\mathrm{w}}$ with increasing wind speed. Finally, the parameterization by Marandino et al. (2009, M09) was used in simulation 10 for the same period as B13m. Both newly implemented parameterizations are part of the most recent release MESSy 2.52 .

\subsection{Observational data}

Simulated atmospheric mixing ratios of the trace gases from PWC and PE are compared to observations from ship cam- 

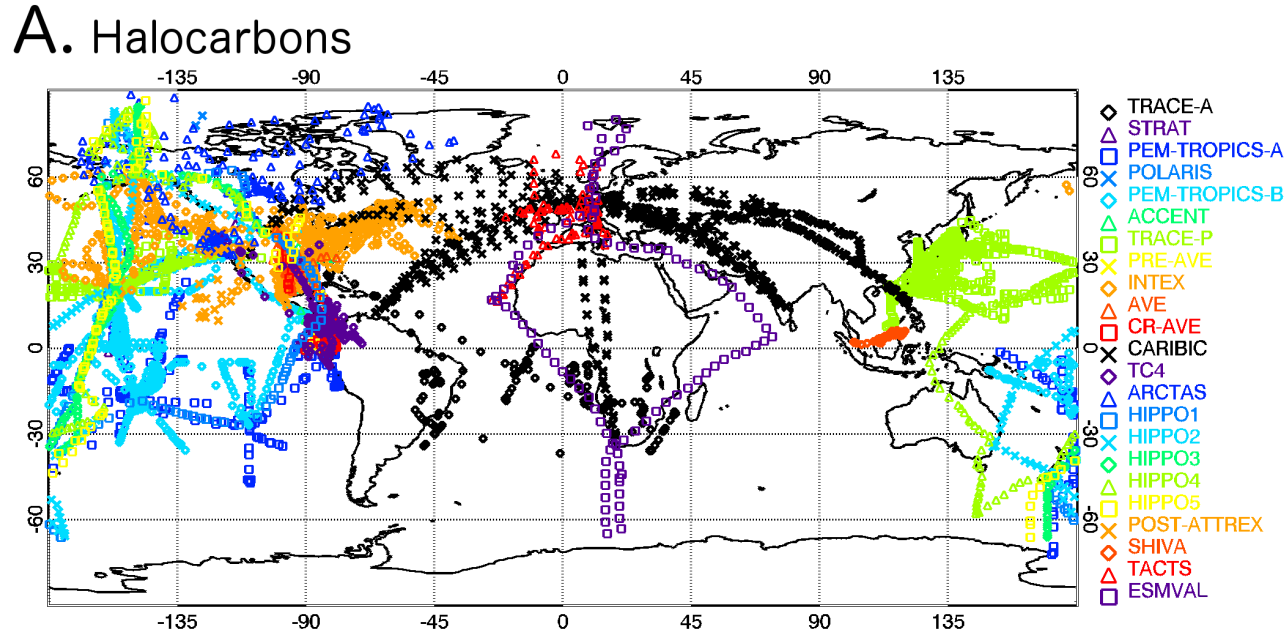

\section{B. DMS}

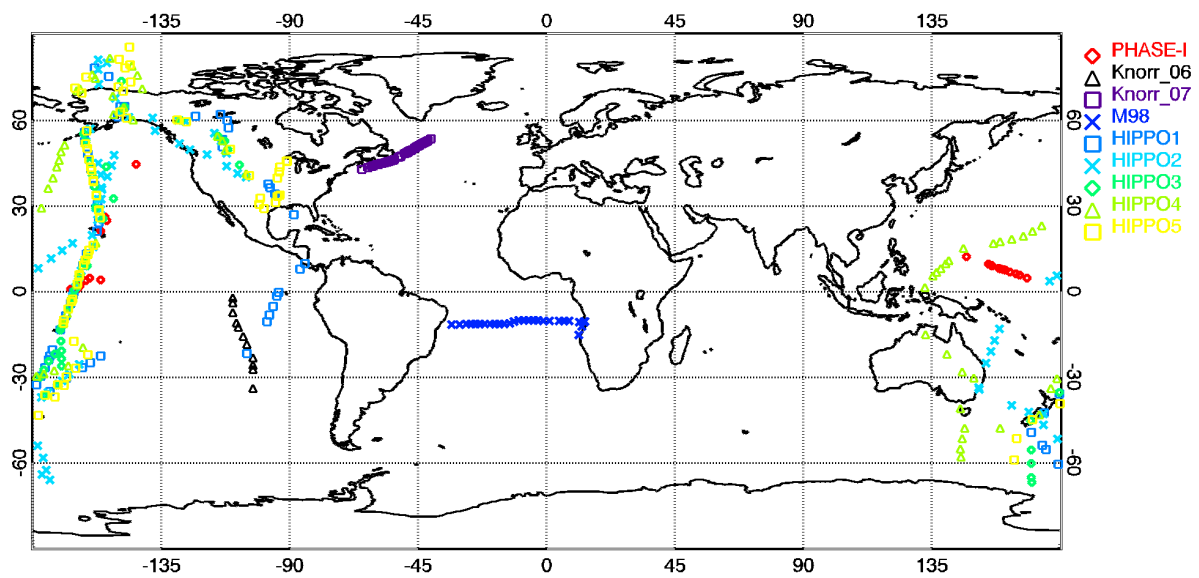

Figure 3. Locations of atmospheric data for comparison with model output used in this study. Panel (a) shows locations of atmospheric measurements from 23 aircraft campaigns considered for comparison with halocarbon simulations. Panel (b) shows location of measurements in the atmospheric boundary layer from ships (PHASE-1, Knorr-06, Knorr-07, M98) and from aircraft campaign (HIPPO 1-5) measurements considered for comparison with DMS simulations.

paigns, aircraft campaigns and ground-based time series stations.

A total of 23 aircraft campaigns providing halocarbon data are considered in order to create annual zonal mean climatologies of these trace gases. The combined data set ranges from $90^{\circ} \mathrm{N}$ to $75^{\circ} \mathrm{S}$, transecting from the surface to the upper troposphere/lower stratosphere over land and ocean from 1992 to 2012 (see Table S1 for details on the aircraft campaigns). Many of the more recent data sets are intercalibrated (see e.g. Brinckmann et al., 2012; Hall et al., 2014; Sala et al., 2014; Wisher et al., 2014). The latitudinal and longitudinal distributions and names of the aircraft campaigns are illustrated in Fig. 3a. The measurements were averaged in zonal $10^{\circ}$ wide latitude bins with a vertical extent ranging from 10 to $50 \mathrm{hPa}(10 \mathrm{hPa}$ in boundary layer and TTL regions). Most of the measurements are located around $30^{\circ} \mathrm{N}$ of latitude with more than 150 points per bin. The tropical region $\left(20^{\circ} \mathrm{N}-20^{\circ} \mathrm{S}\right)$ has an average of 50 points per bin. Figure S1 in the Supplement illustrates the numbers of the measurements per bin. For the comparison of measured and modelled data, the EMAC output of simulations 1 and 2 is first sampled at the same location as the aircraft measurements (longitude, latitude, altitude and time) by linear interpolation. Then, the same process of averaging per bin as for the measurements is applied to the model output.

Nine coastal ground stations from NOAA/ESRL, where halocarbons have been measured by the NOAA global flask sampling network starting from 1990-2004 were chosen for comparison due to their location close to the coast (Table 2). These data are currently available at the HalOcAt (Halocarbons in the Ocean and Atmosphere) database (https://halocat. geomar.de/). Two time series stations situated distant to the coast (Park Falls, Wisconsin, Niwot Ridge Forest, Colorado, both USA) were chosen to assess to contribution of marine 
Table 2. Metadata of the ground-based time series stations of halocarbons (NOAA) considered in this study. For DMS, the data from time series of Cape Grim and Amsterdam Island were considered.

\begin{tabular}{rllllll}
\hline Nr. & Abbr. & Station name & Latitude & Longitude & Elevation $(\mathrm{m})$ & Period \\
\hline 1 & ALT & Alert, Canada & $82.45^{\circ} \mathrm{N}$ & $62.51^{\circ} \mathrm{W}$ & 210 & $1992-2011$ \\
2 & AMS & Amsterdam Island & $37.80^{\circ} \mathrm{S}$ & $77.54^{\circ} \mathrm{E}$ & 55 & $1990-1999$ \\
3 & SUM & Summit, Greenland & $72.58^{\circ} \mathrm{N}$ & $38.48^{\circ} \mathrm{W}$ & 3209 & $2004-2011$ \\
4 & BRW & Barrow, Alaska & $71.32^{\circ} \mathrm{N}$ & $156.61^{\circ} \mathrm{W}$ & 27 & $1993-2011$ \\
5 & MHD & Mace Head, Ireland & $53.33^{\circ} \mathrm{N}$ & $9.90^{\circ} \mathrm{W}$ & 42 & $1998-2011$ \\
6 & LEF & Park Falls, Wisconsin & $45.95^{\circ} \mathrm{N}$ & $90.27^{\circ} \mathrm{W}$ & 868 & $1996-2011$ \\
7 & THD & Trinidad Head, California & $41.05^{\circ} \mathrm{N}$ & $124.151^{\circ} \mathrm{W}$ & 120 & $2002-2011$ \\
8 & NWR & Niwot Ridge Forest, Colorado & $40.03^{\circ} \mathrm{N}$ & $105.55^{\circ} \mathrm{W}$ & 3475 & $1993-2011$ \\
9 & KUM & Cape Kumukahi, Hawaii & $19.5^{\circ} \mathrm{N}$ & $154.8^{\circ} \mathrm{E}$ & 39 & $1995-2011$ \\
10 & MLO & Mauna Loa, Hawaii & $19.53^{\circ} \mathrm{N}$ & $155.58^{\circ} \mathrm{W}$ & 3433 & $1993-2011$ \\
11 & CGO & Cape Grim, Tasmania & $40.68^{\circ} \mathrm{S}$ & $144.69^{\circ} \mathrm{E}$ & 164 & $1993-2011$ \\
12 & PSA & Palmer Station, Antarctica & $64.92^{\circ} \mathrm{S}$ & $64.00^{\circ} \mathrm{W}$ & 15 & $1997-2011$ \\
13 & SPO & South Pole & $90.00^{\circ} \mathrm{S}$ & $59.00^{\circ} \mathrm{E}$ & 2837 & $1993-2011$ \\
\hline
\end{tabular}

halocarbon emissions to the atmospheric mixing ratio over land. Monthly means of the time series were compared to monthly means of simulations 1 and 2 for the PWC and PE set-up.

DMS was directly compared to measurements from ship campaigns in the marine boundary layer, because only few data from ground-based time series stations is available. The campaigns chosen were PHASE-I (2004, Marandino et al., 2007), two campaigns on RV Knorr (Marandino et al., 2007, 2008), and M98 on RV Meteor (2009, A. C. Zavarsky, personal communication, 2014) to ensure a broad spatial coverage (Fig. 3b). Additionally, DMS data from two time series stations - Cape Grim, Australia, 1990-1993 (Ayers et al., 1995) and Amsterdam Island in the Indian Ocean, 19901999 (Sciare et al., 2000) - were used for comparison (Table 2). Upper air atmospheric concentrations of DMS were compared to aircraft measurements from the HIAPER Poleto-Pole observation (HIPPO) campaigns 1-5 (Wofsy et al., 2012), again subsampling the model output for time and location of the observations.

\section{Results and discussion}

\subsection{Global emissions based on prescribed concentrations}

The long-term mean of global emissions (1990-2013, simulation 1 in Table 1) based on PWC is different from the offline calculated emission climatologies for all four gases. The magnitude of this difference varies between the gases $+11 \%(\mathrm{CHBr} 3)$ to $-28 \%\left(\mathrm{CH}_{2} \mathrm{Br}_{2}\right)$ (Table 3$)$. The global spatial pattern of the PWC emissions is similar to the spatial patterns in Z13 and L11 (Figs. 4, 5). Although global emissions for $\mathrm{CH}_{2} \mathrm{Br}_{2}$ were reduced in the PWC set-up compared to the Z13 scenario, they still lie in the range of previously published estimates $\left(61.8-112.7 \mathrm{Tg} \mathrm{yr}^{-1}\right.$; Table 3$)$.
The global PWC emissions for $\mathrm{CHBr}_{3}$ are $11 \%$ higher than from Z13, but still 47-60\% lower than top-down approaches by Warwick et al. (2006), Liang et al. (2010) and Ordóñez et al. (2012). The PWC $\mathrm{CHBr}_{3}$ emissions lie at the lower end of emission scenarios, closest to Z13. The same holds for $\mathrm{CH}_{3} \mathrm{I}$, where emissions are $2 \%$ higher compared to $\mathrm{Z} 13$ but still $18 \%$ lower than the published estimate from Bell et al. (2002). Emission estimates in PWC are closest to Z13 and thus at the lower end of the range of published global emission estimates. DMS emissions in PWC compared to L11 were $17 \%$ lower (Table 3 ).

The main differences between PE and PWC result from considering the actual state of the atmosphere when calculating emissions from PWC, since the atmospheric mixing ratio of the gas has a direct feedback on its emissions through the concentration gradient (Eq. 1). Higher atmospheric concentrations lead to lower marine emissions (or can even lead to deposition) and vice versa. In the PWC set-up where the actual concentration gradient between the ocean surface concentration and the model's atmospheric mixing ratio is considered, the emissions thus respond consistently to this feedback. The most obvious example for that is the global emission of DMS. In L11, an atmospheric concentration of $0 \mathrm{ppt}$ is assumed justified by the high supersaturation in the water and the short lifetime of DMS. In the PWC approach in our study, the atmospheric mixing ratio is always higher than $0 \mathrm{ppt}$, on average $133( \pm 125) \mathrm{ppt}$, and this is likely the main reason for the resulting $17 \%$ reduction in the modelled flux vs. L11 (Fig. 5).

Considering the actual state of the atmosphere leads to altered concentration gradients and thus emissions for any gas in the PWC set-up, but the impact on global emissions depends on the specific characteristics and global distribution of the gas in the surface ocean. For example, the impact of the PWC approach on global emissions for $\mathrm{CH}_{2} \mathrm{Br}_{2}(28 \%$ difference between PWC and Z13) is larger than that for $\mathrm{CH}_{3} \mathrm{I}$ 


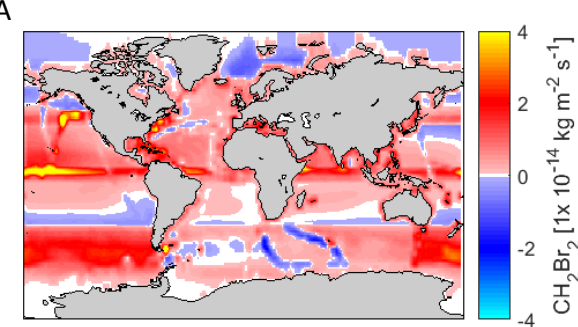

B

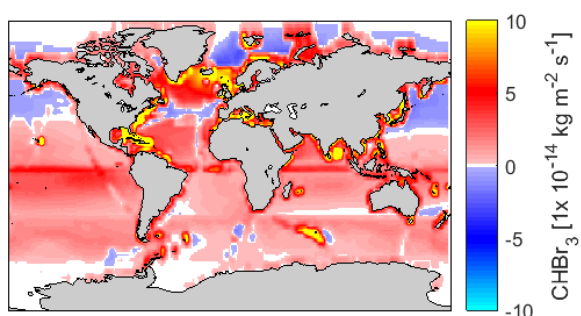

C

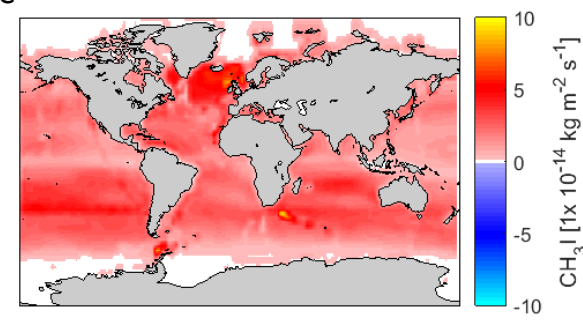

D

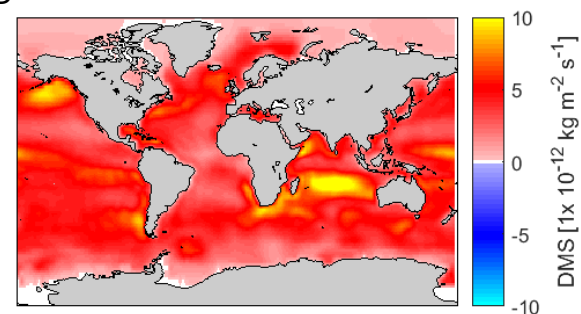

Figure 4. Emissions from PWC (NO0 parameterization for $\left.k_{\mathrm{W}}\right)$ for the trace gases dibromomethane $\left(\mathrm{CH}_{2} \mathrm{Br}_{2}\right.$, panel a), bromoform $\left(\mathrm{CHBr}_{3}\right.$, panel b), methyliodide $\left(\mathrm{CH}_{3} \mathrm{I}\right.$, panel c) and dimethyl sulfide (DMS, panel d), their annual mean of the period 1990-2013 (simulation 1, Table 1).

(2\% difference) (Table 3). This difference can be explained by the saturation of the two gases: $\mathrm{CH}_{3} \mathrm{I}$ is mainly oversaturated in the surface ocean with a mean saturation ratio (actual concentration divided by equilibrium concentration) of 18.2 in $\mathrm{Z13} \mathrm{CH}_{2} \mathrm{Br}_{2}$ with a mean saturation ratio of 2 is concentrated closer to equilibrium. The distance from equilibrium is thus larger for $\mathrm{CH}_{3} \mathrm{I}$ than for $\mathrm{CH}_{2} \mathrm{Br}_{2}$. Changes in atmospheric mixing ratio therefore affect the concentration gradient for $\mathrm{CH}_{2} \mathrm{Br}_{2}$ more than for $\mathrm{CH}_{3} \mathrm{I}$. For $\mathrm{CHBr}_{3}$ with a similar global ocean surface saturation ratio as $\mathrm{CH}_{2} \mathrm{Br}_{2}$, a drastic change in emissions between PWC and Z13 can be seen in the Southern Hemisphere (50-90 S; Table 3), where the emissions increase 2 orders of magnitude in the PWC compared to Z13. The Z13 emission climatology displays a latitudinal band of elevated atmospheric mixing ratios around $60^{\circ} \mathrm{S}$, which result in this region being a sink for atmospheric $\mathrm{CHBr}_{3}$. In our PWC set-up, atmospheric mixing ratios in this region are not as elevated and hence PWC leads to larger emissions. In general, gases that are concentrated close to equilibrium in the surface ocean respond more strongly to changes in atmospheric concentrations and thus to the PWC set-up than more supersaturated gases.

Comparing integrated regional fluxes, the halocarbons display the largest differences in the polar regions (Table 3). Besides dynamic atmospheric concentrations that may alter emissions in the PE set-up, two other reasons for differences in this specific set-up apply for the halocarbons. First, no sea ice is considered in Z13 whereas EMAC uses prescribed sea ice in our PWC set-up. L11 considers sea-ice. When sea ice is present in the model EMAC/AIRSEA, the flux is reduced by the fraction of surface that is covered by it. This may lead to the lower flux estimations in our PWC set-up and may partly explain e.g. the reduced emissions in the Arctic for $\mathrm{CHBr}_{3}$. Furthermore, our PWC approach takes into account air-side transfer velocity (Eq. 2) instead of only the water-side transfer velocity as Z13, which can control the flux of more soluble gases at low temperatures and thus decrease emissions (McGillis et al., 2000). At high latitudes $\left(60-90^{\circ} \mathrm{N}\right.$ and S), where low temperatures and high winds prevail, the transfer velocity can be reduced by up to $68 \%\left(\mathrm{CH}_{2} \mathrm{Br}_{2}\right), 32 \%$ $\left(\mathrm{CHBr}_{3}\right)$ and $61 \%\left(\mathrm{CH}_{3} \mathrm{I}\right)$ using $k_{\text {air }}$ in the PWC set-up. L11 takes the $k_{\text {air }}$ and sea ice into account, so this difference does not apply.

\subsection{Atmospheric mixing ratios based on PWC and PE}

The atmospheric mixing ratios in EMAC sustained by emissions either from PWC or PE are compared to available atmospheric observations from aircraft campaigns (halocarbons, DMS), ground-based time series stations from NOAA/ESRL (halocarbons) and ship campaigns (DMS). The model output of simulations 1 and 2 (Tables 1,4) was subsampled at the times and locations of the observations. A scatterplot for direct comparison between model output and observations is provided in the Supplement in Fig. S2.

The largest difference between PWC and PE in the atmospheric mixing ratio is again found for $\mathrm{CH}_{2} \mathrm{Br}_{2}$ in the Southern Hemisphere (Fig. 6), where the PWC set-up yields lower emissions and therefore also lower atmospheric mixing ratios. For $\mathrm{CH}_{2} \mathrm{Br}_{2}$, atmospheric mixing ratios globally decrease on average by $28 \%$ compared to the PE set-up, which is the same percentage as the reduction in the global emissions. Concentrations derived from these reduced fluxes generally agree better with the measurements, even though Arctic emissions still seem to be underestimated in the model 

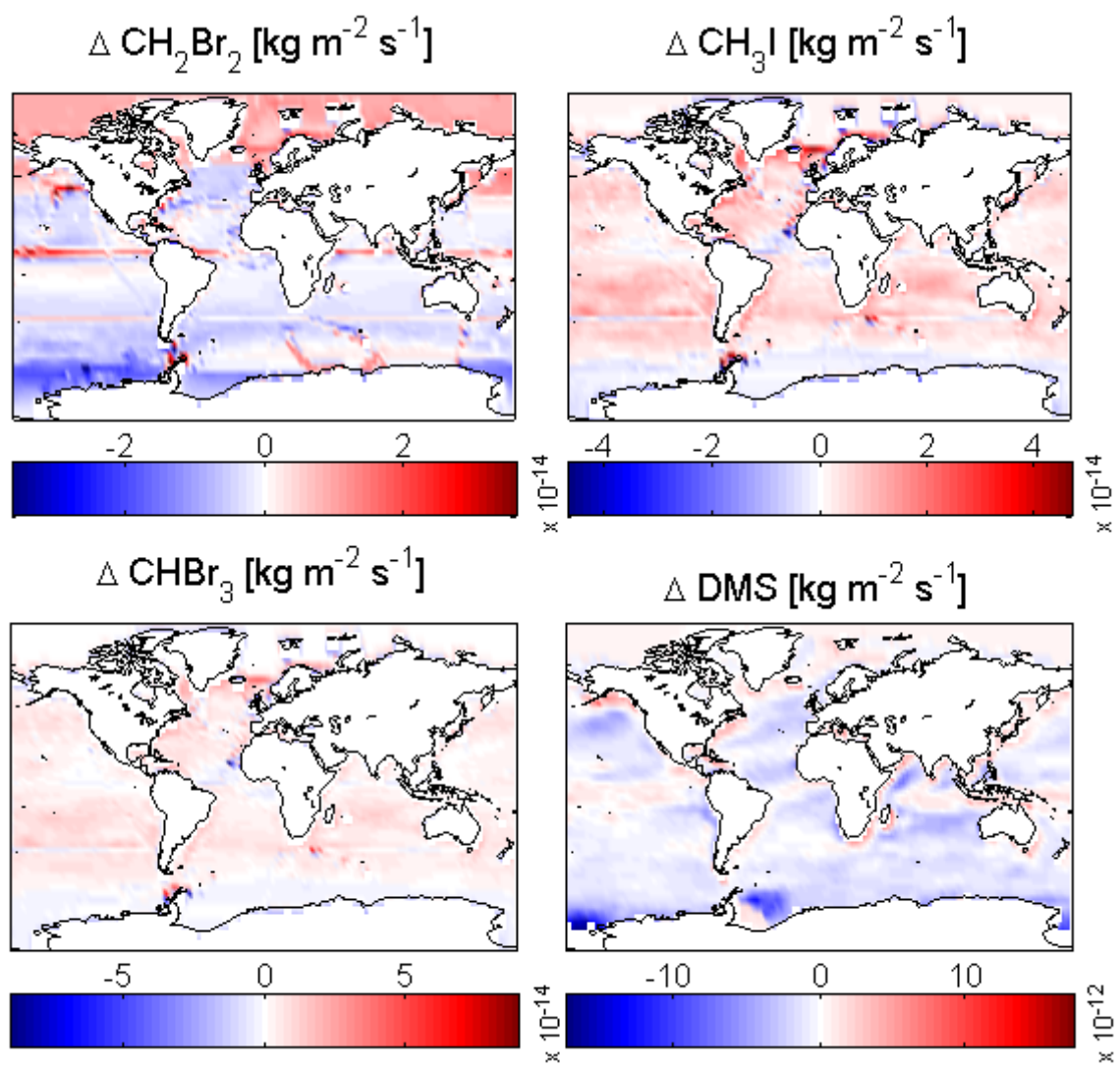

Figure 5. Differences (PWC-PE) in emissions between PWC (simulation 1, Table 1, 2010-2011) and PE (simulation 2, Table 1, 2010-2011). Red indicates a larger flux in the PWC set-up, blue a larger one in the PE set-up.

compared to the observations. A possible explanation for this underestimation could be emissions of VSLS from sea ice that are not considered in the model, as e.g. Karlsson et al. (2013) observed elevated $\mathrm{CH}_{2} \mathrm{Br}_{2}$ in brines on top of sea ice. Mixing ratios of $\mathrm{CHBr}_{3}$ are similar in the PWC and PE set-ups (difference globally only $1.2 \%$ ), but both do not show the same pattern as the measurements: for both set-ups, atmospheric mixing ratios are underestimated in the Southern Hemisphere up to the northern tropics (Fig. 6). The same is evident for $\mathrm{CH}_{3} \mathrm{I}$, where PWC and PE also vary only slightly, while both set-ups underestimate atmospheric $\mathrm{CH}_{3} \mathrm{I}$ concentration in the tropics. Since atmospheric concentrations were derived from emissions based on the Z13/L11 water concentration climatology in the PWC set-up, negative discrepancies to atmospheric observations indicate regions where the concentration climatologies lack hotspots and can thus identify missing oceanic source regions. For all three halocarbons, the concentration climatologies seem to represent water concentrations that are too low in the Northern Hemisphere and the tropics to explain the observed atmospheric mixing ratios. It has to be noted that coastal areas are large source regions of halocarbon emissions with global contributions of up to $70 \%$ (Ziska et al., 2013), which might be underrepresented in our modelled approach and thus might at least partly explain these missing sources.

Modelled concentrations matched observations from NOAA/ESRL ground stations in most of the cases better in the PWC set-up compared to PE. The agreement between simulation and measurements increases with the atmospheric lifetime of the gases: modelled mixing ratios for $\mathrm{CH}_{2} \mathrm{Br}_{2}$, with the longest lifetime of the tested gases, reflect the observed seasonality at all 12 stations well (Fig. 7). The modelled seasonality of the atmospheric mixing ratios is similar in both the PWC and PE set-ups, indicating that the main fluctuations at these locations comes from seasonality in atmospheric transport and chemistry rather than from seasonality in emissions, since emissions are constant in PE. For all stations except for Mace Head, PWC yields atmospheric mixing ratios closer to the measurements for $\mathrm{CH}_{2} \mathrm{Br}_{2}$, reducing overestimations of modelled atmospheric mixing ratios compared to measurements of up to $75 \%$ as e.g. at the South Pole. Discrepancies between observations and model simulations are larger in most of the ground-based stations for $\mathrm{CHBr}_{3}$ (lifetime $\sim 20$ days in our simulation) than for $\mathrm{CH}_{2} \mathrm{Br}_{2}$, and again PWC yields as good or more accurate mixing ratios than $\mathrm{PE}$ compared to the measurements (Fig. 8). However, the observed seasonality is not well re- 

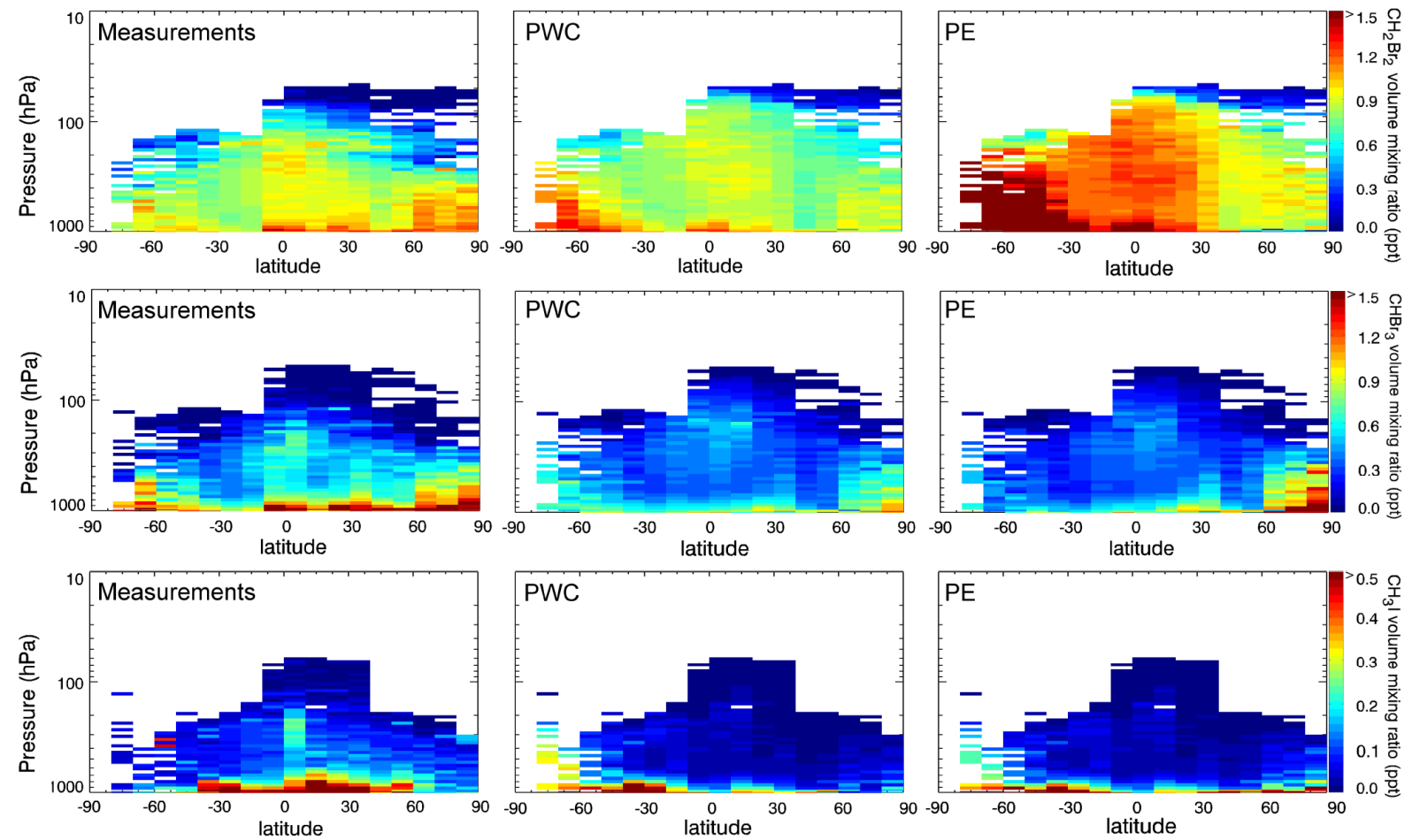

Figure 6. Atmospheric mixing ratios (in ppt) of the trace gases dibromomethane $\left(\mathrm{CH}_{2} \mathrm{Br}_{2}\right.$, upper row), bromoform $(\mathrm{CHBr} 3$, middle row), and methyliodide $\left(\mathrm{CH}_{3} \mathrm{I}\right.$, lower row) derived from measurements (see Fig. 3 for locations of aircraft campaigns) and EMAC runs with prescribed water concentrations and prescribed emissions. Model output was subsampled at locations and times of observations and binned for direct comparison.

flected in either the PWC or the PE set-up. This mismatch indicates that a further seasonality in the sources is required, which can e.g. be accounted for by introducing a seasonality in the water concentrations prescribed. This finding is opposite to findings from Liang et al. (2010), who concluded that atmospheric $\mathrm{CHBr}_{3}$ mixing ratios are mainly driven by transport and atmospheric chemistry. Furthermore, the good agreement between model and observations at continental sites away from the coast (Park Falls, Wisconsin, USA; Niwot Ridge Forest, Colorado, USA) for $\mathrm{CH}_{2} \mathrm{Br}_{2}$ and $\mathrm{CHBr}_{3}$ indicates that the ocean is the dominant source of these compounds also over land. $\mathrm{CH}_{3} \mathrm{I}$, the gas with the shortest lifetime in the range of a few days, shows the largest discrepancies between modelled mixing ratios and observations (Fig. 9). The PWC set-up yields mixing ratios in the range of the observations for only two stations (Alert, Canada, and Barrow, Alaska, USA) and, in most of the stations, the seasonality was not well reflected in the model runs. $\mathrm{CH}_{3} \mathrm{I}$ seasonality in water concentrations has previously been observed (Shi et al., 2014), indicating that seasonally resolved water concentrations are needed to reproduce atmospheric concentrations of the shortest-lived compounds in a more accurate way. Oceanic emissions in PE and PWC were too large to explain atmospheric mixing ratios at stations in high latitudes (Summit, Mace Head, Cape Grim, Palmer Station,
South Pole), but too low to explain atmospheric mixing ratios in lower latitudes (Park Falls, Trinidad Head, Niwot Ridge, Cape Kumukahi, Mauna Loa), which agrees with findings from aircraft campaigns (Fig. 6).

Four ship campaigns were chosen for comparison of DMS, since only few long-term measurements of atmospheric mixing ratios of DMS are available. Simulation with both the PWC (NO0) and the PE approach overestimate DMS mixing ratios in the marine boundary layer from ship campaigns (see positive mean bias in Table 5). However, the PWC reduces discrepancies within both ship and aircraft campaigns by a factor of 2 (Table 5), as the mixing ratio is overestimated by a factor of 0.61 in PWC as opposed to 1.31 in PE. The observed seasonality of DMS mixing ratios at Amsterdam Island is well reflected in the simulations except for the summer months, where PWC and PE overestimate the monthly mean by a factor of up to 4.6 (PWC) and 6.7 (PE) (Fig. 10). At Amsterdam Island, the simulated annual mean atmospheric mixing ratio of $180.7 \mathrm{ppt}$ in the PWC set-up agrees very well with the observed annual mean of $181.2 \mathrm{ppt}$, whereas the simulated annual mean in the PE setup is 268.5 ppt. At Cape Grim, the results of the two set-ups do not differ that much, and both simulations underestimate the mixing ratios measured during austral summer. 

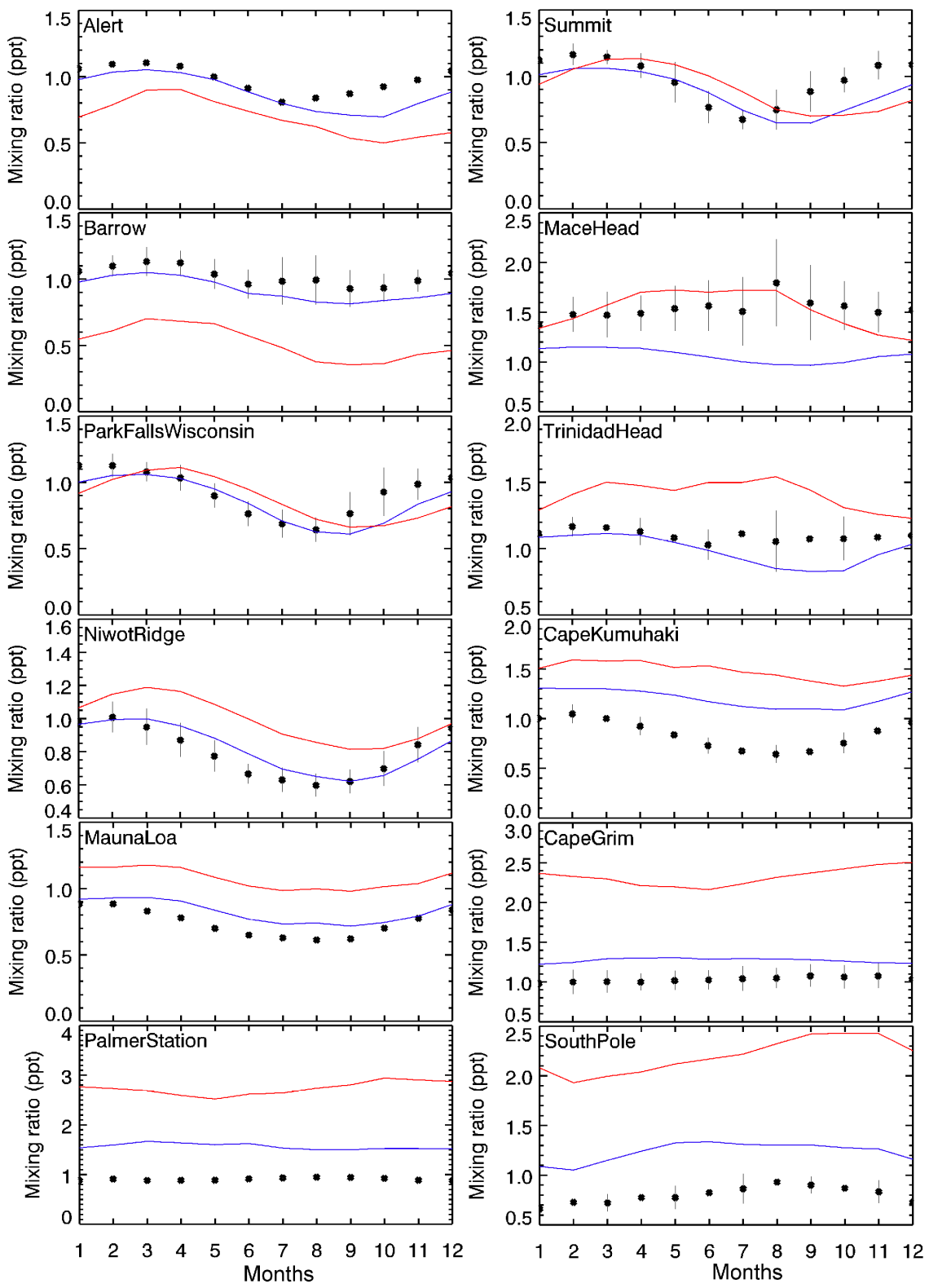

Figure 7. Mean seasonal variation of $\mathrm{CH}_{2} \mathrm{Br}_{2}$ mixing ratios (in ppt) using model output based on $\mathrm{PE}$ (in red) and PWC (in blue), subsampled at the location of the NOAA ground-based time series stations. Black dots indicate the long-term monthly means of the time series at the specific locations ( \pm standard deviation of the monthly means), vertical lines indicate the corresponding standard deviations. Monthly time series of at least 7 years were averaged, the exact periods are listed in Table 2.

An overall comparison of the agreement of both setups with observations is summarized in a Taylor diagram (Fig. 11). This diagram is a statistical summary that shows how well two patterns match each other with regard to their correlation, variance and root-mean-square difference (Taylor, 2001). The closer a point of a specific set-up is located to the reference point of observations (here 1.0 on $x$ axis), the more the simulation resembles the observed measurements. PWC simulations increased the agreement with observations for $\mathrm{CH}_{2} \mathrm{Br}_{2}$, especially the correlation (0.4 in $\mathrm{PE}$ to 0.6 in
PWC), and for DMS (0.53 in PE to 0.65 in PWC), but only very slightly for $\mathrm{CHBr}_{3}$ and $\mathrm{CH}_{3} \mathrm{I}$. Centred statistics for all compounds can be found in Table 5, with the equations used to compute the statistics according to Yu et al. (2006) listed in the Supplement.

\subsection{Comparison of different transfer velocity $\left(k_{\mathrm{w}}\right)$ parameterizations}

A large uncertainty of global emission estimates is related to different parameterizations of the transfer velocity in Eq. (1). 

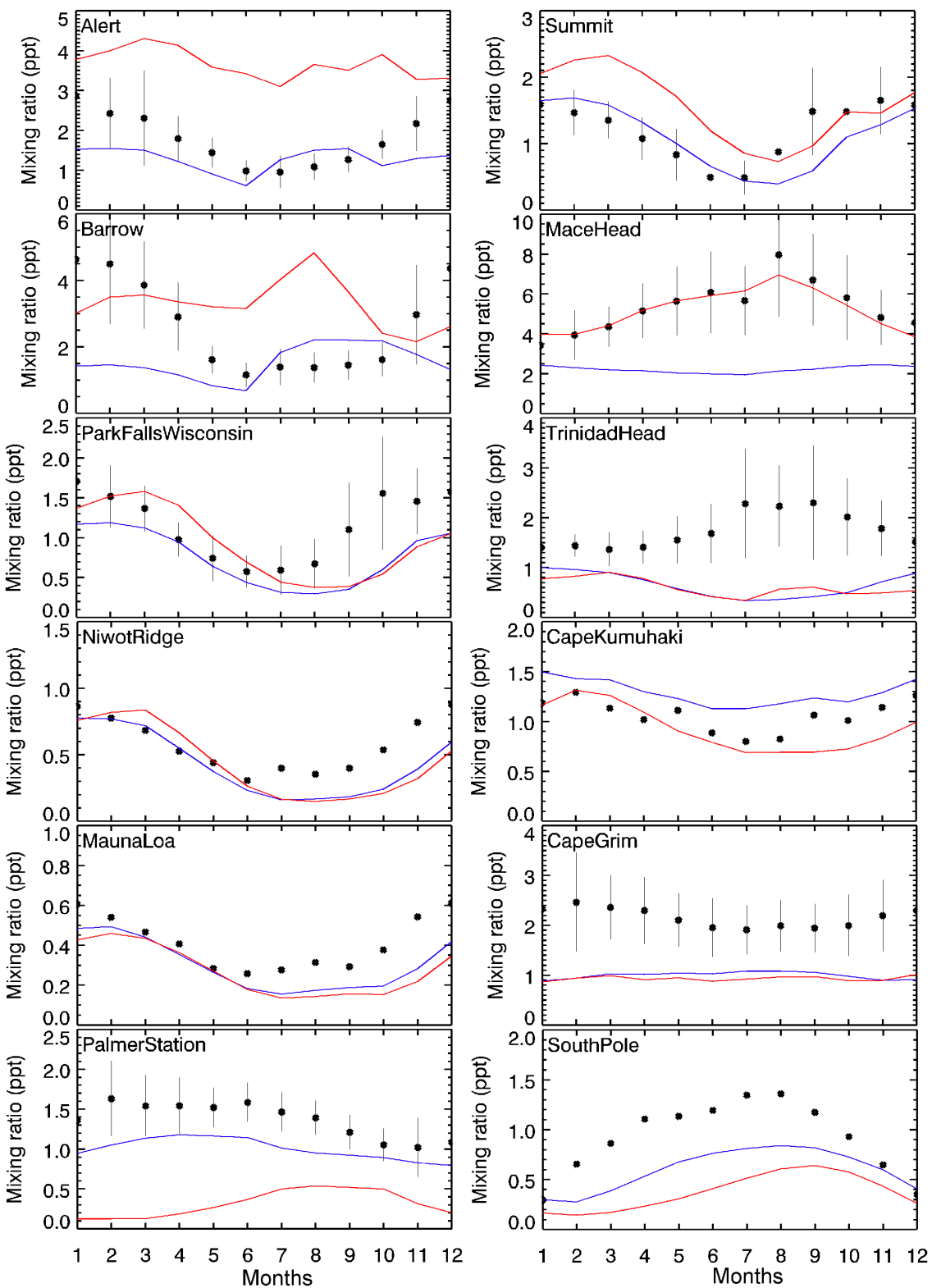

Figure 8. Same as Fig. 7, for $\mathrm{CHBr}_{3}$.

Calculating emissions online enables a simple way of testing different transfer velocity parameterizations, which was realized here with eight 2-year simulations described in Table 1 (simulations 3-10).

The largest sensitivity for the emissions of all gases is introduced by different parameterizations of the water-side transfer velocity $k_{\mathrm{w}}$ tested in simulations $3-6$ (Table 4 ). The 4 parameterizations that were tested (simulation 3-6, Table 1) comprised linear (LM86, simulation 3), cubic (W99, simulation 4) and quadratic (N00, simulation 5, H06, simulation 6) relations to wind speed. The resulting global emission estimates in these parameterizations range 53.765.1 $\mathrm{Gg} \mathrm{yr}^{-1}$ for $\mathrm{CH}_{2} \mathrm{Br}_{2}, 189.0-249.7 \mathrm{Gg} \mathrm{yr}^{-1}$ for $\mathrm{CHBr}_{3}$,
151.9-225.7 $\mathrm{Gg} \mathrm{yr}^{-1}$ for $\mathrm{CH}_{3} \mathrm{I}$ and $33.4-48.7 \mathrm{Tg} \mathrm{yr}^{-1}$ for DMS (Table 4). As expected, the linear $k_{\mathrm{w}}$ parameterization (LM86) yields the lowest global emission estimates, since it produces the lowest $k_{\mathrm{w}}$ values (Fig. 2). The N00 parameterization produces the highest global fluxes for $\mathrm{CHBr}_{3}$ and $\mathrm{CH}_{2} \mathrm{Br}_{2}$ but not for DMS and $\mathrm{CH}_{3} \mathrm{I}$, where the highest fluxes were obtained by H06 (DMS) and W99 $\left(\mathrm{CH}_{3} \mathrm{I}\right)$ (Table 4). The fact that different parameterizations lead to higher global estimates for different gases is explained by the varying spatial distribution of concentration hot spots and regional variations of wind.

The $k_{\mathrm{w}}$ parameterization in simulation 7 increases the flux under calm conditions due to precipitation. This increase 

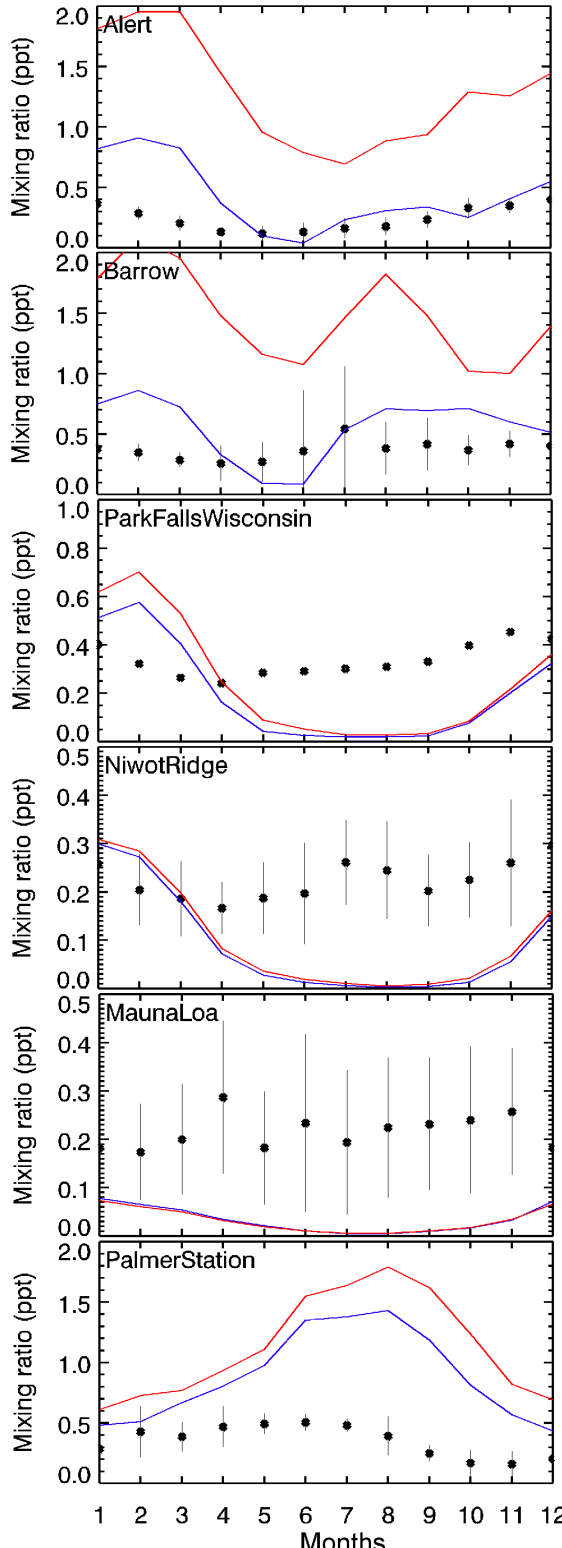

Figure 9. Same as Fig. 7, for $\mathrm{CH}_{3} \mathrm{I}$.

ranged from $4 \%\left(\mathrm{CH}_{2} \mathrm{Br}_{2}\right)$ to $6 \%$ (DMS) (Table 4$)$ when compared to the reference flux using H06 alone (simulation 6, Table 4). Additional flux due to precipitation is inversely correlated to the Schmidt number, so that under identical conditions, increasing flux would be added in the order $\mathrm{CHBr}_{3}>\mathrm{CH}_{2} \mathrm{Br}_{2}>\mathrm{DMS}>\mathrm{CH}_{3}$ I. The global flux estimations compared to the reference run do not increase in this order (Table 4), rather DMS $>\mathrm{CHBr}_{3} \sim \mathrm{CH}_{3} \mathrm{I}>\mathrm{CH}_{2} \mathrm{Br}_{2}$. This non-uniform response among the gases is explained by the globally and regionally varying distance from equilibrium for the four gases, which together with regional precipitation patterns leads to variations in the emissions increased by rain. The parameterization based on white-cap coverage

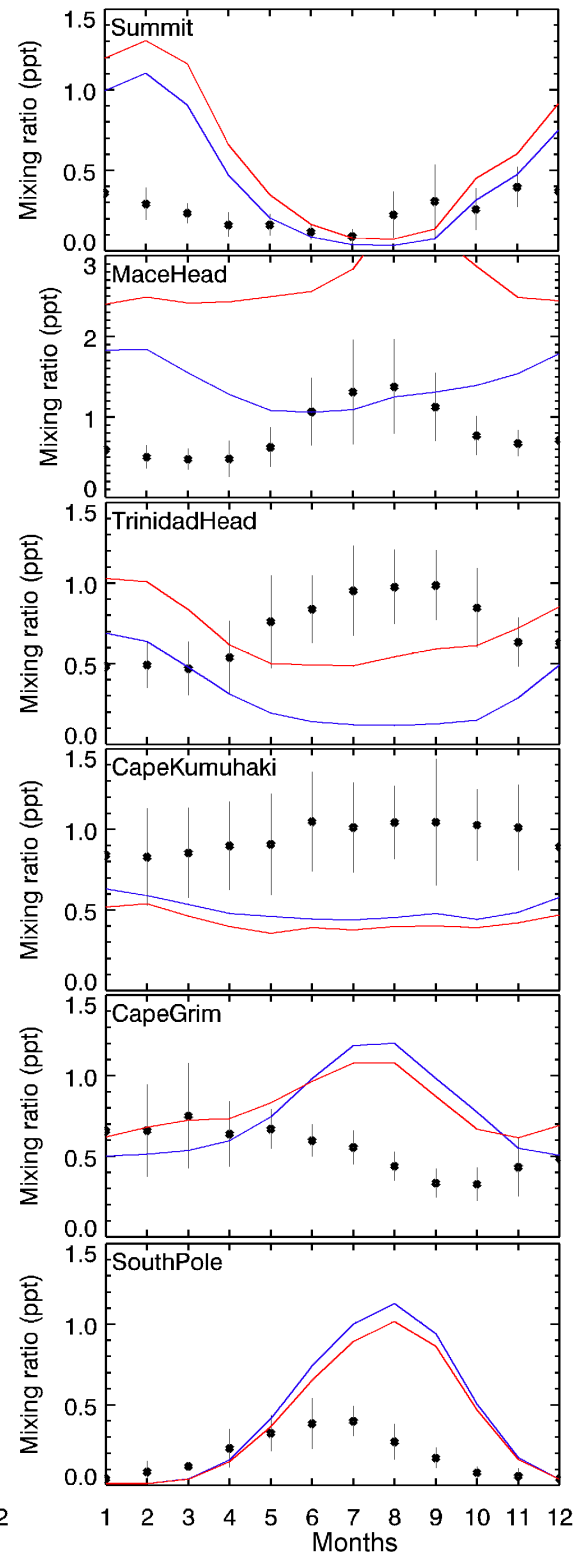

(A98) also has small but ambivalent effects on the global flux for the different compounds (simulation 8, Table 4). Compared to the mean of all nonlinear parameterizations for each gas, global emissions were higher when the white cap coverage parameterization was used for $\mathrm{CHBr}_{3}(4 \%)$ and $\mathrm{CH}_{2} \mathrm{Br}_{2}$ (2\%) but lower for $\mathrm{CH}_{3} \mathrm{I}(-8 \%)$ and DMS $(-6 \%)$ (Table 4$)$.

The parameterizations tested only for DMS are both derived from eddy covariance measurements at sea. Both parameterizations changed the global emissions by $-4.4 \%$ (B13m) and $-1.2 \%$ (M09) compared to the average flux of simulations 3-6 (Table 4). Although the modelled atmospheric mixing ratios at the time and location of observations is for both of the parameterizations higher than the observa- 

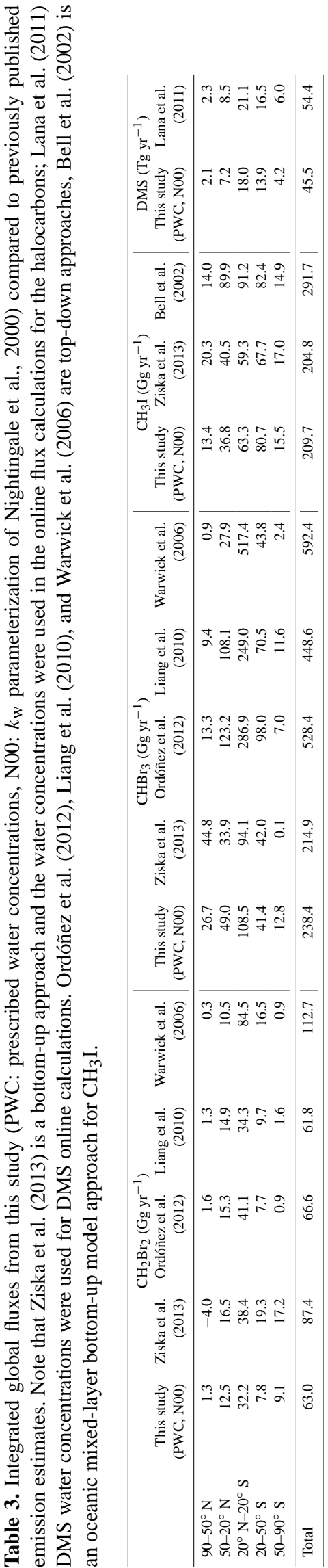

A

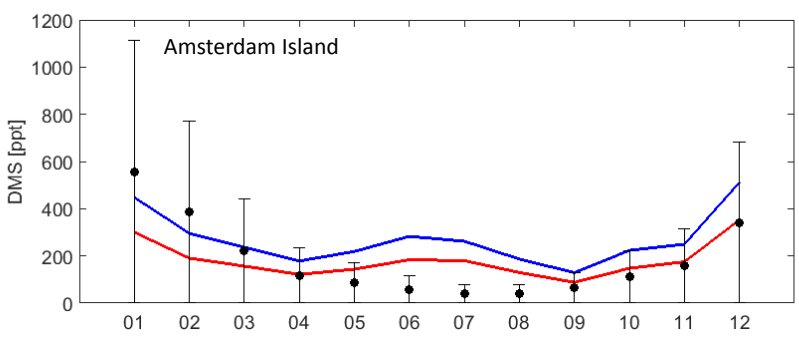

B

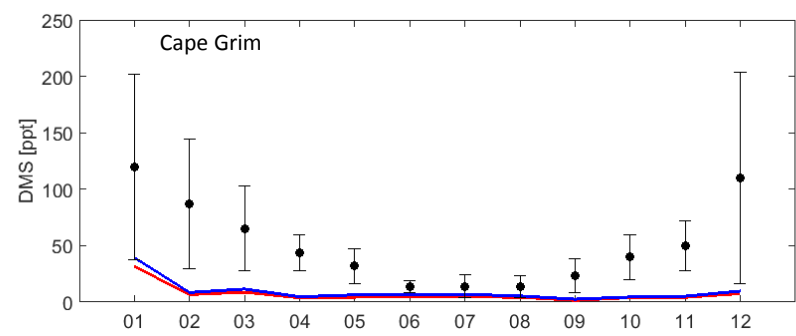

Figure 10. Same as Fig. 7, for DMS.

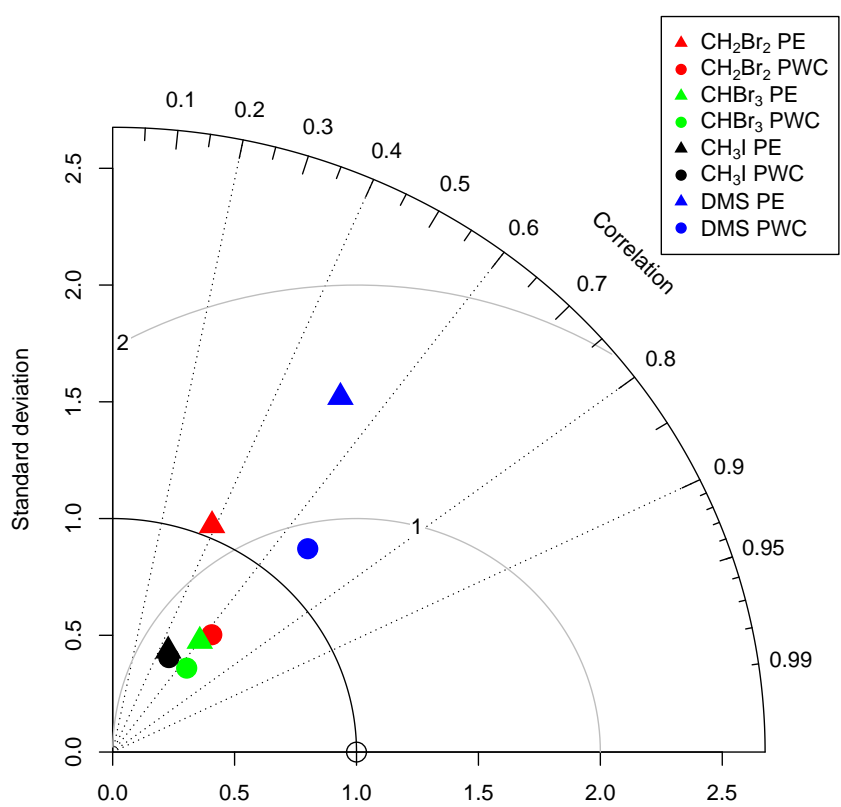

Figure 11. Taylor diagram of PE (triangles) compared to PWC (circles) runs using the same parameterization for $k_{\mathrm{W}}(\mathrm{N} 00)$ for comparison. The Taylor diagram relates model simulations to observations according to their root-mean-square error (given as the distance to the reference point, $x$ axis 1.0), correlation and standard deviation. Simulations located closest to the reference point agree best with observations. 
Table 4. Integrated global emissions during 2010-2011 for sensitivity tests using different parameterizations for the transfer velocity $k_{\mathrm{W}}$ (simulations 3-6, same as in Table 1) and the effects of rain (simulation 7), bubble-mediated transfer parameterized using white cap coverage (simulation 8) and parameterizations recently suggested for DMS (simulations 9 and 10). Equations for the parameterizations using wind speed $u$ are given for the Schmidt number (subscript after $k$ ) as in the original publications listed. $u$ : wind speed at $10 \mathrm{~m}$ a.s.l. in metres per second. $k$ is given in centimetres per hour.

\begin{tabular}{|c|c|c|c|c|c|c|}
\hline No. & Parameterization & $\mathrm{CH}_{2} \mathrm{Br}_{2}$ & $\begin{array}{r}\mathrm{CHBr}_{3} \\
\mathrm{Gg} \mathrm{yr}^{-1}\end{array}$ & $\begin{array}{r}\mathrm{CH}_{3} \mathrm{I} \\
\mathrm{Gg} \mathrm{yr}^{-1}\end{array}$ & $\begin{array}{r}\text { DMS } \\
\mathrm{Gg} \mathrm{yr}^{-1}\end{array}$ & $\operatorname{Tg}_{\mathrm{yr}}{ }^{-1}$ \\
\hline 3 & Liss and Merlivat (1986) & $\begin{array}{l}\text { for } u \leq 3.6, k_{660}=0.17 u \\
\text { for } 3.6<u<13, k_{660}=2.85 u-9.65 \\
\text { for } u \geq 13, k_{660}=5.9 u\end{array}$ & 53.74 & 189.10 & 151.88 & 33.38 \\
\hline 4 & Wanninkhof et al. (1999) & $k_{660}=0.0283 u^{3}$ & 58.38 & 211.17 & 223.52 & 45.22 \\
\hline 5 & Nightingale et al. (2000) & $k_{600}=0.22 u^{2}+0.333 u$ & 63.04 & 238.46 & 209.73 & 45.49 \\
\hline 6 & Ho et al. (2006) & $k_{660}=0.266 u^{2}$ & 62.71 & 236.10 & 213.47 & 45.91 \\
\hline 7 & Ho et al. $(2006)+$ rain & - & 65.08 & 249.66 & 225.67 & 48.70 \\
\hline 8 & White cap coverage & - & 62.76 & 238.51 & 197.44 & 42.53 \\
\hline 9 & Bell et al. (2013), modified & $\begin{array}{l}\text { for } u \leq 11, k_{600}=0.22 u^{2}+0.333 u \\
\text { for } u>11, k_{600}=30.283\end{array}$ & - & - & - & 40.63 \\
\hline \multirow[t]{2}{*}{10} & Marandino et al. (2009) & $k_{720}=1.92 u-1.0^{*}$ & - & - & - & 42.45 \\
\hline & Mean (simulations 3-6) & & 59.47 & 218.71 & 199.65 & 42.5 \\
\hline
\end{tabular}

* Units converted, in original publication: $k_{720}=0.46 u-0.24\left(\mathrm{~m} \mathrm{day}^{-1}\right)$.

Table 5. Error metrics for the comparison of model output from PWC (simulation 1) and PE (simulation 2) for all of the compounds including all aircraft campaigns and ship observations, illustrated in Fig. S2 in the Supplement. Determination of error metrics according to Yu et al. (2006).

\begin{tabular}{|c|c|c|c|c|c|c|c|c|}
\hline & $\mathrm{CH}_{2} \mathrm{Br}_{2} \mathrm{PE}$ & $\mathrm{CH}_{2} \mathrm{Br}_{2} \mathrm{PWC}$ & $\mathrm{CHBr}_{3} \mathrm{PE}$ & $\mathrm{CHBr}_{3} \mathrm{PWC}$ & $\mathrm{CH}_{3} \mathrm{I} \mathrm{PE}$ & $\mathrm{CH}_{3} \mathrm{I}$ PWC & DMS PE & DMS PWC \\
\hline Mean bias (ppt) & 0.24 & -0.036 & -0.23 & -0.24 & -0.14 & -0.14 & 86.21 & 42.12 \\
\hline Mean absolute gross error (ppt) & 0.30 & 0.15 & 0.31 & 0.31 & 0.15 & 0.16 & 102.9 & 67.39 \\
\hline RMSE (ppt) & 0.381 & 0.21 & 0.53 & 0.53 & 0.26 & 0.26 & 236.2 & 135.8 \\
\hline Fractional bias (ppt) & 0.26 & 0.0001 & -0.23 & -0.20 & -0.89 & -0.96 & 0.23 & 0.10 \\
\hline Fractional absolute error (ppt) & 0.31 & 0.20 & 0.56 & 0.56 & 1.13 & 1.19 & 1.23 & 1.18 \\
\hline Normalized mean bias factor $(-)$ & 0.27 & -0.04 & -0.49 & -0.53 & -1.71 & -1.96 & 1.31 & 0.64 \\
\hline
\end{tabular}

tions, discrepancies between simulated and observed mixing ratios were reduced compared to the N00 parameterization by factors of $1.4(\mathrm{~B} 13 \mathrm{~m})$ and $1.2(\mathrm{M} 09)$.

\section{Summary and conclusions}

Two different ways of considering marine emissions of trace gases in global atmospheric chemistry models are discussed here for the halocarbons $\mathrm{CH}_{2} \mathrm{Br}_{2}, \mathrm{CHBr}_{3}, \mathrm{CH}_{3} \mathrm{I}$ and the sulfur-containing compound DMS. In contrast to prescribing emissions (PE) from oceanic and atmospheric concentration climatologies in the model, prescribing water concentrations (PWC) with an online calculation of emissions results in a consistent concentration gradient between ocean and atmosphere. The approach of modelling emissions online was successfully applied for the very short-lived halocarbons for the first time. The approach is based on the submodel AIRSEA coupled to EMAC by Pozzer et al. (2006). The method has a number of conceptual and practical advantages, as in this framework the modelled flux can respond in a consistent way to changes in sea surface temperature, surface wind speed, possible sea ice cover and marine atmospheric mixing ratios in the model.

Global emission estimates of the four gases differ between $+11 \%\left(\mathrm{CHBr}_{3}\right)$ and $-28 \%\left(\mathrm{CH}_{2} \mathrm{Br}_{2}\right)$ between PWC and PE when the transfer velocity $k_{\mathrm{w}}$ is parameterized according to Nightingale et al. (2000) in both set-ups. Prescribing water concentrations instead of emissions has the strongest effect for gases close to equilibrium in the surface ocean such as $\mathrm{CH}_{2} \mathrm{Br}_{2}$ (28\% reduced emissions in PWC compared to PE), as its emissions are most sensitive to atmospheric concentrations. In contrast, only a $2 \%$ difference is found for the highly supersaturated gas $\mathrm{CH}_{3} \mathrm{I}$. Considering PWC reduces the global emissions of DMS by $17 \%$, a comparison to observations revealed that $\mathrm{PWC}$ compared to $\mathrm{PE}$ reproduces observations slightly $\left(\mathrm{CHBr}_{3}, \mathrm{CH}_{3} \mathrm{I}\right)$ or much $\left(\mathrm{CH}_{2} \mathrm{Br}_{2}\right.$, DMS $)$ better for measurements made at ground-based time series stations, aircraft campaigns and ship cruises. Even though it is clear that more data for all compounds are needed globally, the PWC set-up can be used to identify oceanic regions 
where more measurements will be needed to improve the global emission estimate. For example, there are clear discrepancies in the Northern Hemisphere for $\mathrm{CHBr}_{3}$ and the tropics for $\mathrm{CH}_{3} \mathrm{I}$.

Global emission estimates display a large sensitivity towards the parameterization of the transfer velocity $k_{\mathrm{w}}$, with relative differences between $15.6 \%\left(\mathrm{CH}_{2} \mathrm{Br}_{2}\right)$ and $35.9 \%\left(\mathrm{CH}_{3} \mathrm{I}\right)$ compared to the mean global emissions of the four tested simulations including $k_{\mathrm{w}}$ parameterizations according to Liss and Merlivat (1986, LM86), Wanninkhof and McGillis (1999, W99), Nightingale et al. (2000, N00) and Ho et al. (2006, H06). Sensitivity towards rain or bubble-mediated transfer was generally low $(<10 \%$ change in global emission estimate). Two parameterizationadapting results that have recently been suggested for DMS (Marandino et al., 2009, M09; Bell et al., 2013, B13m) produced both a lower global emission estimate, which at the same time reduced discrepancies between simulated and observed atmospheric mixing ratios and yielded simulated atmospheric mixing ratios closer to observations than simulated mixing ratios with the N00 parameterization.

In summary, prescribing water concentrations instead of prescribing emissions in global atmospheric chemistry models leads to a consistent concentration gradient between ocean and atmosphere and enables convenient testing of different air-sea gas exchange parameterizations. Based on the results of our comparison between the PE and PWC, prescribing concentrations leads to more consistent emissions and mainly more accurate reproduction of observations of atmospheric mixing ratios of the VSLS described here.

\section{The Supplement related to this article is available online at doi:10.5194/acp-15-11753-2015-supplement.}

Acknowledgements. This work was supported through the German Federal Ministry of Education and Research through the project ROMIC-THREAT (BMBF-FK01LG1217A and 01LG1217B). Additional funding for $\mathrm{C}$. Marandino and S. Lennartz came from the Helmholtz Young Investigator Group of C. Marandino, TRASE-EC (VH-NG-819), from the Helmholtz Association through the President's Initiative and Networking Fund and the GEOMAR Helmholtz-Zentrum für Ozeanforschung Kiel. We thank A. Pozzer for advice on the use of AIRSEA and valuable comments on the manuscript. Thanks to Donald R. Blake from the University of California, Irvine for advice and the data access. Thanks to A. Lana for providing emission and concentration fields of DMS and to A. C. Zavarsky for atmospheric DMS measurements on the Meteor 98 cruise. We thank Prabir Patra for his help and for providing the $\mathrm{OH}$ field used in the EMAC simulations. NOAA measurements were supported in part by NOAA's Atmospheric Chemistry, Carbon Cycle and Climate Program of its Climate program Office. Data on halocarbon mixing ratios from aircraft campaigns were obtained from the ESPO NASA archive and from the EOL-NCAR database.
We acknowledge operational, technical and scientific support provided by NCAR's Earth Observing Laboratory, sponsored by the National Science Foundation. The University of Frankfurt would like to thank the DLR for organizing and funding the ESMVal campaign and DFG (grant no. 367/8 and EN367/11) for funding the TACTS campaign and the measurements.

Edited by: L. M. Russell

\section{References}

Aschmann, J., Sinnhuber, B.-M., Atlas, E. L., and Schauffler, S. M.: Modeling the transport of very short-lived substances into the tropical upper troposphere and lower stratosphere, Atmos. Chem. Phys., 9, 9237-9247, doi:10.5194/acp-9-9237-2009, 2009.

Asher, W. E. and Wanninkhof, R.: The effect of bubblemediated gas transfer on purposeful dual-gaseous tracer experiments, J. Geophys. Res.-Oceans, 103, 10555-10560, doi:10.1029/98jc00245, 1998.

Ayers, G. P., Bentley, S. T., Ivey, J. P., and Forgan, B. W.: Dimethylsulfide in marine air at cape grim, $41^{\circ} \mathrm{s}$, J. Geophysical Res.Atmos., 100, 21013-21021, doi:10.1029/95jd02144, 1995.

Barnes, I., Hjorth, J., and Mihalopoulos, N.: Dimethyl sulfide and dimethyl sulfoxide and their oxidation in the atmosphere, Chemical Rev., 106, 940-975, doi:10.1021/cr020529+, 2006.

Bates, T. S., Lamb, B. K., Guenther, A., Dignon, J., and Stoiber, R. E.: Sulfur emissions to the atmosphere from natural sources, J. Atmos. Chem., 14, 315-337, doi:10.1007/bf00115242, 1992.

Bell, N., Hsu, L., Jacob, D. J., Schultz, M. G., Blake, D. R., Butler, J. H., King, D. B., Lobert, J. M., and Maier-Reimer, E.: Methyl iodide: Atmospheric budget and use as a tracer of marine convection in global models, J. Geophys. Res.-Atmos., 107, 4340, doi:10.1029/2001jd001151, 2002.

Bell, T. G., De Bruyn, W., Miller, S. D., Ward, B., Christensen, K. H., and Saltzman, E. S.: Air-sea dimethylsulfide (DMS) gas transfer in the North Atlantic: evidence for limited interfacial gas exchange at high wind speed, Atmos. Chem. Phys., 13, 1107311087, doi:10.5194/acp-13-11073-2013, 2013.

Brinckmann, S., Engel, A., Bönisch, H., Quack, B., and Atlas, E.: Short-lived brominated hydrocarbons - observations in the source regions and the tropical tropopause layer, Atmos. Chem. Phys., 12, 1213-1228, doi:10.5194/acp-12-1213-2012, 2012.

Burrows, S. M., Ogunro, O., Frossard, A. A., Russell, L. M., Rasch, P. J., and Elliott, S. M.: A physically based framework for modeling the organic fractionation of sea spray aerosol from bubble film Langmuir equilibria, Atmos. Chem. Phys., 14, 1360113629, doi:10.5194/acp-14-13601-2014, 2014.

Cameron-Smith, P., Elliott, S., Maltrud, M., Erickson, D., and Wingenter, O.: Changes in dimethyl sulfide oceanic distribution due to climate change, Geophys. Res. Lett., 38, L07704, doi:10.1029/2011GL047069, 2011.

Chameides, W. L. and Davis, D. D.: Iodine - its possible role in tropospheric photochemistry, J. Geophys. Res.-Oceans Atmos., 85, 7383-7398, doi:10.1029/JC085iC12p07383, 1980.

Charlson, R. J., Lovelock, J. E., Andreae, M. O., and Warren, S. G.: Oceanic phytoplankton, atmospheric sulfur, cloud albedo and climate, Nature, 326, 655-661, doi:10.1038/326655a0, 1987. 
De Bruyn, W. J., Swartz, E., Hu, J. H., Shorter, J. A., Davidovits, P., Worsnop, D. R., Zahniser, M. S., and Kolb, C. E.: Henrys law solubilities and setcheniw coefficients for biogenic reduced sulphur species obtained from gas-liquid uptake measurements, J. Geophys. Res.-Atmos., 100, 7245-7251, doi:10.1029/95JD00217, 1995.

Dee, D. P., Uppala, S. M., Simmons, A. J., Berrisford, P., Poli, P., Kobayashi, S., Andrae, U., Balmaseda, M. A., Balsamo, G., Bauer, P., Bechtold, P., Beljaars, A. C. M., van de Berg, L., Bidlot, J., Bormann, N., Delsol, C., Dragani, R., Fuentes, M., Geer, A. J., Haimberger, L., Healy, S. B., Hersbach, H., Hólm, E. V., Isaksen, L., Kållberg, P., Köhler, M., Matricardi, M., McNally, A. P., Monge-Sanz, B. M., Morcrette, J. J., Park, B. K., Peubey, C., de Rosnay, P., Tavolato, C., Thépaut, J. N., and Vitart, F.: The erainterim reanalysis: Configuration and performance of the data assimilation system, Q. J. Roy. Meteorol. Soc., 137, 553-597, doi:10.1002/qj.828, 2011.

Elliott, S., Burrows, S. M., Deal, C., Liu, X., Long, M., Ogunro, O., Russell, L. M., and Wingenter, O.: Prospects for simulating macromolecular surfactant chemistry at the ocean-atmosphere boundary, Environ. Res. Lett., 9, 064012, doi:10.1088/17489326/9/6/064012, 2014.

Hall, B. D., Engel, A., Mühle, J., Elkins, J. W., Artuso, F., Atlas, E., Aydin, M., Blake, D., Brunke, E.-G., Chiavarini, S., Fraser, P. J., Happell, J., Krummel, P. B., Levin, I., Loewenstein, M., Maione, M., Montzka, S. A., O’Doherty, S., Reimann, S., Rhoderick, G., Saltzman, E. S., Scheel, H. E., Steele, L. P., Vollmer, M. K., Weiss, R. F., Worthy, D., and Yokouchi, Y.: Results from the International Halocarbons in Air Comparison Experiment (IHALACE), Atmos. Meas. Tech., 7, 469-490, doi:10.5194/amt-7469-2014, 2014.

Hayduk, W. and Laudie, H.: Prediction of diffusion coefficients for nonelectrolytes in dilute aqueous solutions, AIChE Journal, 20, 611-615, doi:10.1002/aic.690200329, 1974.

Hepach, H., Quack, B., Raimund, S., Fischer, T., Atlas, E. L., and Bracher, A.: Halocarbon emissions and sources in the equatorial Atlantic Cold Tongue, Biogeosciences Discuss., 12, 5559-5608, doi:10.5194/bgd-12-5559-2015, 2015.

Ho, D. T., Bliven, L. F., Wanninkhof, R., and Schlosser, P.: The effect of rain on air-water gas exchange, Tellus B, 49, 149-158, 1997.

Ho, D. T., Zappa, C. J., McGillis, W. R., Bliven, L. F., Ward, B., Dacey, J. W. H., Schlosser, P., and Hendricks, M. B.: Influence of rain on air-sea gas exchange: Lessons from a model ocean, J. Geophys. Res.-Oceans, 109, C08S18, doi:10.1029/2003jc001806, 2004.

Ho, D. T., Law, C. S., Smith, M. J., Schlosser, P., Harvey, M., and Hill, P.: Measurements of air-sea gas exchange at high wind speeds in the southern ocean: Implications for global parameterizations, Geophys. Res. Lett., 33, L16611, doi:10.1029/2006g1026817, 2006.

Hopkins, F. E. and Archer, S. D.: Consistent increase in dimethyl sulfide (DMS) in response to high $\mathrm{CO}_{2}$ in five shipboard bioassays from contrasting NW European waters, Biogeosciences, 11, 4925-4940, doi:10.5194/bg-11-4925-2014, 2014.

Hossaini, R., Chipperfield, M. P., Monge-Sanz, B. M., Richards, N. A. D., Atlas, E., and Blake, D. R.: Bromoform and dibromomethane in the tropics: a 3-D model study of chemistry and transport, Atmos. Chem. Phys., 10, 719-735, doi:10.5194/acp10-719-2010, 2010.

Hossaini, R., Mantle, H., Chipperfield, M. P., Montzka, S. A., Hamer, P., Ziska, F., Quack, B., Krüger, K., Tegtmeier, S., Atlas, E., Sala, S., Engel, A., Bönisch, H., Keber, T., Oram, D., Mills, G., Ordóñez, C., Saiz-Lopez, A., Warwick, N., Liang, Q., Feng, W., Moore, F., Miller, B. R., Marécal, V., Richards, N. A. D., Dorf, M., and Pfeilsticker, K.: Evaluating global emission inventories of biogenic bromocarbons, Atmos. Chem. Phys., 13, 11819-11838, doi:10.5194/acp-13-11819-2013, 2013.

Hossaini, R., Chipperfield, M. P., Montzka, S. A., Rap, A., Dhomse, S., and Feng, W.: Efficiency of short-lived halogens at influencing climate through depletion of stratospheric ozone, Nat. Geosci., 8, 186-190, doi:10.1038/ngeo2363, 2015.

Hough, A.: The calculation of photolysis rates for use in global tropospheric modelling studies, UKAEA Atomic Energy Research Establishment Environmental and Medical Sciences Division, UK, 54 pp., 1988.

Jöckel, P.: Technical note: Recursive rediscretisation of geoscientific data in the Modular Earth Submodel System (MESSy), Atmos. Chem. Phys., 6, 3557-3562, doi:10.5194/acp-6-35572006, 2006.

Jöckel, P., Tost, H., Pozzer, A., Brühl, C., Buchholz, J., Ganzeveld, L., Hoor, P., Kerkweg, A., Lawrence, M. G., Sander, R., Steil, B., Stiller, G., Tanarhte, M., Taraborrelli, D., van Aardenne, J., and Lelieveld, J.: The atmospheric chemistry general circulation model ECHAM5/MESSy1: consistent simulation of ozone from the surface to the mesosphere, Atmos. Chem. Phys., 6, 50675104, doi:10.5194/acp-6-5067-2006, 2006.

Jöckel, P., Kerkweg, A., Pozzer, A., Sander, R., Tost, H., Riede, H., Baumgaertner, A., Gromov, S., and Kern, B.: Development cycle 2 of the Modular Earth Submodel System (MESSy2), Geosci. Model Dev., 3, 717-752, doi:10.5194/gmd-3-717-2010, 2010.

Karlsson, A., Theorin, M., and Abrahamsson, K.: Distribution, transport, and production of volatile halocarbons in the upper waters of the ice-covered high arctic ocean, Global Biogeochem. Cy., 27, 1246-1261, doi:10.1002/2012gb004519, 2013.

Kerkweg, A., Buchholz, J., Ganzeveld, L., Pozzer, A., Tost, H., and Jöckel, P.: Technical Note: An implementation of the dry removal processes DRY DEPosition and SEDImentation in the Modular Earth Submodel System (MESSy), Atmos. Chem. Phys., 6, 4617-4632, doi:10.5194/acp-6-4617-2006, 2006a.

Kerkweg, A., Sander, R., Tost, H., and Jöckel, P.: Technical note: Implementation of prescribed (OFFLEM), calculated (ONLEM), and pseudo-emissions (TNUDGE) of chemical species in the Modular Earth Submodel System (MESSy), Atmos. Chem. Phys., 6, 3603-3609, doi:10.5194/acp-6-3603-2006, 2006 b.

Kloster, S., Feichter, J., Maier-Reimer, E., Six, K. D., Stier, P., and Wetzel, P.: DMS cycle in the marine ocean-atmosphere system a global model study, Biogeosciences, 3, 29-51, doi:10.5194/bg3-29-2006, 2006.

Kondo, J.: Air-sea bulk transfer coefficients in diabatic conditions, Bound.-Lay. Meteorol., 9, 91-112, doi:10.1007/bf00232256, 1975.

Lana, A., Bell, T. G., Simo, R., Vallina, S. M., Ballabrera-Poy, J., Kettle, A. J., Dachs, J., Bopp, L., Saltzman, E. S., Stefels, J., Johnson, J. E., and Liss, P. S.: An updated climatology of surface dimethlysulfide concentrations and emission fluxes 
in the global ocean, Global Biogeochem. Cy., 25, GB1004, doi:10.1029/2010gb003850, 2011.

Liang, Q., Stolarski, R. S., Kawa, S. R., Nielsen, J. E., Douglass, A. R., Rodriguez, J. M., Blake, D. R., Atlas, E. L., and Ott, L. E.: Finding the missing stratospheric Bry: a global modeling study of $\mathrm{CHBr}_{3}$ and $\mathrm{CH} 2 \mathrm{Br}_{2}$, Atmos. Chem. Phys., 10, 2269-2286, doi:10.5194/acp-10-2269-2010, 2010.

Lin, S. J. and Rood, R. B.: Multidimensional fluxform semi-lagrangian transport schemes, Mon. Weather Rev., 124, 2046-2070, doi:10.1175/15200493(1996)124<2046:MFFSLT>2.0.CO;2, 1996.

Liss, P. and Slater, P.: Flux of gases across the air-sea interface, Nature, 247, 181-184, 1974.

Liss, P. S. and Merlivat, L.: Air-sea gas exchange rates: Introduction and synthesis, in: The role of air-sea gas exchange in geochemical cycling, edited by: Buat-Menard, P., Reidel, D., Norwell, Mass., 113-127, 1986.

Lovelock, J. E. and Maggs, R. J.: Halogenated hydrocarbons in and over the atlantic, Nature, 241, 194-196, doi:10.1038/241194a0, 1973.

Lyman, W., Reehl, W., and Rosenblatt, D.: Handbook of chemical property estimation mehods, American Chemical Society, Washington DC, USA, 1990.

Marandino, C. A., De Bruyn, W. J., Miller, S. D., and Saltzman, E. S.: Eddy correlation measurements of the air/sea flux of dimethylsulfide over the north pacific ocean, J. Geophys. Res.Atmos., 112, D03301, doi:10.1029/2006jd007293, 2007.

Marandino, C. A., De Bruyn, W. J., Miller, S. D., and Saltzman, E. S.: DMS air/sea flux and gas transfer coefficients from the north atlantic summertime coccolithophore bloom, Geophys. Res. Lett., 35, L23812, doi:10.1029/2008g1036370, 2008.

Marandino, C. A., De Bruyn, W. J., Miller, S. D., and Saltzman, E. S.: Open ocean DMS air/sea fluxes over the eastern South Pacific Ocean, Atmos. Chem. Phys., 9, 345-356, doi:10.5194/acp9-345-2009, 2009.

Marandino, C. A., Tegtmeier, S., Krüger, K., Zindler, C., Atlas, E. L., Moore, F., and Bange, H. W.: Dimethylsulphide (DMS) emissions from the western Pacific Ocean: a potential marine source for stratospheric sulphur?, Atmos. Chem. Phys., 13, 8427-8437, doi:10.5194/acp-13-8427-2013, 2013a.

Marandino, C. A., Tegtmeier, S., Krüger, K., Zindler, C., Atlas, E. L., Moore, F., and Bange, H. W.: Corrigendum to "Dimethylsulphide (DMS) emissionsfrom the West Pacific Ocean: a potential marine source for stratospheric sulphur?" published in Atmos. Chem. Phys., 13, 8427-8437, 2013, Atmos. Chem. Phys., 13, 8813-8814, doi:10.5194/acp-13-8813-2013, 2013b.

McGillis, W. R., Dacey, J. W. H., Frew, N. M., Bock, E. J., and Nelson, R. K.: Water-air flux of dimethylsulfide, J. Geophys. Res.Oceans, 105, 1187-1193, doi:10.1029/1999jc900243, 2000.

Moore, R. M., Geen, C. E., and Tait, V. K.: Determination of henry law constants for a suite of naturally-occurring halogenated methanes in seawater, Chemosphere, 30, 1183-1191, doi:10.1016/0045-6535(95)00009-w, 1995.

Nightingale, P. D., Malin, G., Law, C. S., Watson, A. J., Liss, P. S., Liddicoat, M. I., Boutin, J., and Upstill-Goddard, R. C.: In situ evaluation of air-sea gas exchange parameterizations using novel conservative and volatile tracers, Global Biogeochem. Cy., 14, 373-387, doi:10.1029/1999gb900091, 2000.
O’Dowd, C. D. and De Leeuw, G.: Marine aerosol production: A review of the current knowledge, Philos. Trans. R. Soc. A-Math. Phys. Eng. Sci., 365, 1753-1774, doi:10.1098/rsta.2007.2043, 2007.

Ordóñez, C., Lamarque, J.-F., Tilmes, S., Kinnison, D. E., Atlas, E. L., Blake, D. R., Sousa Santos, G., Brasseur, G., and Saiz-Lopez, A.: Bromine and iodine chemistry in a global chemistry-climate model: description and evaluation of very short-lived oceanic sources, Atmos. Chem. Phys., 12, 1423-1447, doi:10.5194/acp12-1423-2012, 2012.

Orkin, V. L., Khamaganov, V. G., Kozlov, S. N., and Kurylo, M. J.: Measurements of rate constants for the oh reactions with bromoform (chbr3), chbr2cl, chbrcl2, and epichlorohydrin (c3h5clo), J. Phys. Chem. A, 117, 3809-3818, doi:10.1021/jp3128753, 2013.

Osthoff, H. D., Bates, T. S., Johnson, J. E., Kuster, W. C., Goldan, P., Sommariva, R., Williams, E. J., Lerner, B. M., Warneke, C., de Gouw, J. A., Pettersson, A., Baynard, T., Meagher, J. F., Fehsenfeld, F. C., Ravishankara, A. R., and Brown, S. S.: Regional variation of the dimethyl sulfide oxidation mechanism in the summertime marine boundary layer in the gulf of maine, J. Geophys. Res.-Atmos., 114, D07301, doi:10.1029/2008jd010990, 2009.

Papanastasiou, D. K., McKeen, S. A., and Burkholder, J. B.: The very short-lived ozone depleting substance $\mathrm{CHBr} 3$ (bromoform): revised UV absorption spectrum, atmospheric lifetime and ozone depletion potential, Atmos. Chem. Phys., 14, 30173025, doi:10.5194/acp-14-3017-2014, 2014.

Patra, P. K., Krol, M. C., Montzka, S. A., Arnold, T., Atlas, E. L., Lintner, B. R., Stephens, B. B., Xiang, B., Elkins, J. W., Fraser, P. J., Ghosh, A., Hintsa, E. J., Hurst, D. F., Ishijima, K., Krummel, P. B., Miller, B. R., Miyazaki, K., Moore, F. L., Muehle, J., O’Doherty, S., Prinn, R. G., Steele, L. P., Takigawa, M., Wang, H. J., Weiss, R. F., Wofsy, S. C., and Young, D.: Observational evidence for interhemispheric hydroxyl-radical parity, Nature, 513, 219-223, doi:10.1038/nature13721, 2014.

Penkett, S. A., Jones, B. M. R., Rycroft, M. J., and Simmons, D. A.: An interhemispheric comparison of the concentrations of bromine compounds in the atmosphere, Nature, 318, 550-553, doi:10.1038/318550a0, 1985.

Pozzer, A., Jöckel, P., Sander, R., Williams, J., Ganzeveld, L., and Lelieveld, J.: Technical Note: The MESSy-submodel AIRSEA calculating the air-sea exchange of chemical species, Atmos. Chem. Phys., 6, 5435-5444, doi:10.5194/acp-6-5435-2006, 2006.

Quack, B. and Wallace, D. W. R.: Air-sea flux of bromoform: Controls, rates, and implications, Global Biogeochem. Cy., 17, 1023, doi:10.1029/2002gb001890, 2003.

Saiz-Lopez, A., Plane, J. M. C., Baker, A. R., Carpenter, L. J., von Glasow, R., Martin, J. C. G., McFiggans, G., and Saunders, R. W.: Atmospheric chemistry of iodine, Chemical Rev., 112, 17731804, doi:10.1021/cr200029u, 2012.

Sala, S., Bönisch, H., Keber, T., Oram, D. E., Mills, G., and Engel, A.: Deriving an atmospheric budget of total organic bromine using airborne in situ measurements from the western Pacific area during SHIVA, Atmos. Chem. Phys., 14, 6903-6923, doi:10.5194/acp-14-6903-2014, 2014.

Salawitch, R. J.: Atmospheric chemistry: Biogenic bromine, Nature, 439, 275-277, doi:10.1038/439275a, 2006.

Salawitch, R. J., Weisenstein, D. K., Kovalenko, L. J., Sioris, C. E., Wennberg, P. O., Chance, K., Ko, M. K. W., and McLinden, C. 
A.: Sensitivity of ozone to bromine in the lower stratosphere, Geophys. Res. Lett., 32, L05811, doi:10.1029/2004g1021504, 2005.

Saltzman, E. S., King, D. B., Holmen, K., and Leck, C.: Experimental determination of the diffusion coefficient of dimethylsulfide in water, J. Geophys. Res.-Oceans, 98, 16481-16486, doi:10.1029/93jc01858, 1993.

Sander, R., Baumgaertner, A., Gromov, S., Harder, H., Jöckel, P., Kerkweg, A., Kubistin, D., Regelin, E., Riede, H., Sandu, A., Taraborrelli, D., Tost, H., and Xie, Z.-Q.: The atmospheric chemistry box model CAABA/MECCA-3.0, Geosci. Model Dev., 4, 373-380, doi:10.5194/gmd-4-373-2011, 2011.

Sciare, J., Mihalopoulos, N., and Dentener, F. J.: Interannual variability of atmospheric dimethylsulfide in the southern indian ocean, J. Geophys. Res.-Atmos., 105, 26369-26377, doi:10.1029/2000jd900236, 2000.

Sheng, J.-X., Weisenstein, D. K., Luo, B.-P., Rozanov, E., Stenke, A., Anet, J., Bingemer, H., and Peter, T.: Global atmospheric sulfur budget under volcanically quiescent conditions: Aerosolchemistry-climate model predictions and validation, J. Geophys. Res.-Atmos., 120, 2014JD021985, doi:10.1002/2014jd021985, 2015.

Shi, Q., Petrick, G., Quack, B., Marandino, C., and Wallace, D.: Seasonal variability of methyl iodide in the kiel fjord, J. Geophys. Res.-Oceans, 119, 1609-1620, doi:10.1002/2013jc009328, 2014.

Sinnhuber, B.-M. and Meul, S.: Simulating the impact of emissions of brominated very short lived substances on past stratospheric ozone trends, Geophys. Res. Lett., 42, 2449-2456, doi:10.1002/2014g1062975, 2015.

Sinnhuber, B.-M., Sheode, N., Sinnhuber, M., Chipperfield, M. P., and Feng, W.: The contribution of anthropogenic bromine emissions to past stratospheric ozone trends: a modelling study, Atmos. Chem. Phys., 9, 2863-2871, doi:10.5194/acp-9-2863-2009, 2009.

Solomon, S., Garcia, R. R., and Ravishankara, A. R.: On the role of iodine in ozone depletion, J. Geophys. Res.-Atmos., 99, 2049120499, doi:10.1029/94jd02028, 1994.

Taylor, K. E.: Summarizing multiple aspects of model performance in a single diagram, J. Geophys. Res.-Atmos., 106, 7183-7192, doi:10.1029/2000jd900719, 2001.

Tegtmeier, S., Krüger, K., Quack, B., Atlas, E., Blake, D. R., Boenisch, H., Engel, A., Hepach, H., Hossaini, R., Navarro, M. A., Raimund, S., Sala, S., Shi, Q., and Ziska, F.: The contribution of oceanic methyl iodide to stratospheric iodine, Atmos. Chem. Phys., 13, 11869-11886, doi:10.5194/acp-13-11869-2013, 2013.

Tiedtke, M.: A comprehensive mass flux scheme for cumulus parameterization in large-scale models, Mon. Weather Rev., 117, 1779-1800, doi:10.1175/15200493(1989)117<1779:ACMFSF>2.0.CO;2, 1989.

Tsai, W. T. and Liu, K. K.: An assessment of the effect of sea surface surfactant on global atmosphere-ocean co2 flux, J. Geophys. Res.-Oceans, 108, 3127, doi:10.1029/2000jc000740, 2003.

von Glasow, R., von Kuhlmann, R., Lawrence, M. G., Platt, U., and Crutzen, P. J.: Impact of reactive bromine chemistry in the troposphere, Atmos. Chem. Phys., 4, 2481-2497, doi:10.5194/acp-42481-2004, 2004.
Wanninkhof, R.: Relationship between wind speed and gas exchange over the ocean, J. Geophys. Res., 97, 7373-7382, 1992.

Wanninkhof, R. and McGillis, W. R.: A cubic relationship between air-sea co2 exchange and wind speed, Geophys. Res. Lett., 26, 1889-1892, doi:10.1029/1999g1900363, 1999.

Wanninkhof, R., Asher, W. E., Ho, D. T., Sweeney, C., and McGillis, W. R.: Advances in quantifying air-sea gas exchange and environmental forcing, Ann. Rev. Marine Sci., 1, 213-244, doi:10.1146/annurev.marine.010908.163742, 2009.

Warwick, N. J., Pyle, J. A., Carver, G. D., Yang, X., Savage, N. H., O'Connor, F. M., and Cox, R. A.: Global modeling of biogenic bromocarbons, J. Geophys. Res.-Atmos., 111, D24305, doi:10.1029/2006jd007264, 2006.

Watts, S. F.: The mass budgets of carbonyl sulfide, dimethyl sulfide, carbon disulfide and hydrogen sulfide, Atmos. Environ., 34, 761779, doi:10.1016/s1352-2310(99)00342-8, 2000.

Wilke, C. R. and Chang, P.: Some measurements of diffusion in liquids, J. Phys. Chem., 59, 592-596, 1955.

Wisher, A., Oram, D. E., Laube, J. C., Mills, G. P., van Velthoven, P., Zahn, A., and Brenninkmeijer, C. A. M.: Very short-lived bromomethanes measured by the CARIBIC observatory over the North Atlantic, Africa and Southeast Asia during 2009-2013, Atmos. Chem. Phys., 14, 3557-3570, doi:10.5194/acp-14-35572014, 2014.

Wofsy, S. C., B. C. Daube, R. Jimenez, Kort, E., Pittman, J. V., Park, S., Commane, R., Xiang, B., Santoni, G., Jacob, D., Fisher, J., Pickett-Heaps, C., Wang, H., Wecht, K., Wang, Q.-Q., B.Stephens, B., Shertz, S., Watt, A. S., Romashkin, P., Campos, T., Haggerty, J., Cooper, W. A., Rogers, D., Beaton, S., Hendershot, R., Elkins, J. W., Fahey, D. W., Gao, R. S., Moore, F., Montzka, S. A., Schwarz, J. P., Perring, A. E., Hurst, D., Miller, B. R., Sweeney, C., Oltmans, S., D.Nance, Hintsa, E., Dutton, G., Watts, L. A., Spackman, J. R., Rosenlof, K. H., Ray, E. A., B. Hall, Zondlo, M. A., Diao, M., Keeling, R., Bent, J., Atlas, E. L., Lueb, R., and Mahoney, M. J.: Hippo combined discrete flask and gc sample ghg, halo-, hydrocarbon data (r_20121129), Center, C. d. I. A., Oak Ridge National Laboratory, Oak Ridge, Tenessee, USA, 2012.

Yu, S., Eder, B., Dennis, R., Chu, S.-H., and Schwartz, S. E.: New unbiased symmetric metrics for evaluation of air quality models, Atmos. Sci. Lett., 7, 26-34, doi:10.1002/asl.125, 2006.

Ziska, F., Quack, B., Abrahamsson, K., Archer, S. D., Atlas, E., Bell, T., Butler, J. H., Carpenter, L. J., Jones, C. E., Harris, N. R. P., Hepach, H., Heumann, K. G., Hughes, C., Kuss, J., Krüger, K., Liss, P., Moore, R. M., Orlikowska, A., Raimund, S., Reeves, C. E., Reifenhäuser, W., Robinson, A. D., Schall, C., Tanhua, T., Tegtmeier, S., Turner, S., Wang, L., Wallace, D., Williams, J., Yamamoto, H., Yvon-Lewis, S., and Yokouchi, Y.: Global sea-toair flux climatology for bromoform, dibromomethane and methyl iodide, Atmos. Chem. Phys., 13, 8915-8934, doi:10.5194/acp13-8915-2013, 2013. 